\title{
Synthesis of 6-Substituted 2-Pyrrolyl and Indolyl Benzoxazoles by Intramolecular O-Arylation in Photostimulated Reactions
}

\author{
Victoria A. Vaillard, Javier F. Guastavino, María E. Budén, Javier I. Bardagí, Silvia M. Barolo,
} and Roberto A. Rossi*

INFIQC, Departamento de Química Orgánica, Facultad de Ciencias Químicas, Universidad Nacional de Córdoba, X5000HUA Córdoba. Argentina

Supporting Information

ABSTRACT: The synthesis of a series of 6-substituted 2pyrrolyl and 2-indolyl benzoxazoles by photostimulated $\mathrm{C}-\mathrm{O}$ cyclization of anions from 2-pyrrole carboxamides, 2-indole carboxamides, or 3-indole carboxamides has been found to proceed in good to excellent yields $(41-100 \%)$ in DMSO and liquid ammonia. The pyrrole and indole carboxamides are obtained in good to very good isolated yields by an amidation reaction of different 2-haloanilines with 2-carboxylic acid of pyrrole and 2- or 3-carboxylic acid of indole. To explain the regiochemical outcome of these reactions (C-O arylation vs $\mathrm{C}-\mathrm{N}$ or $\mathrm{C}-\mathrm{C}$ arylation), a theoretical analysis was performed using DFT methods and the B3LYP functional.

\section{INTRODUCTION}

The benzoxazole core is an important type of heterocycle found in many natural products and pharmacological agents (Figure 1).

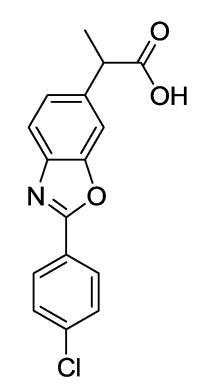

Benoxaprofen<smiles>C=CC[N+]1(C)CCN(c2nc3ccccc3o2)CC1</smiles>

CP 2289

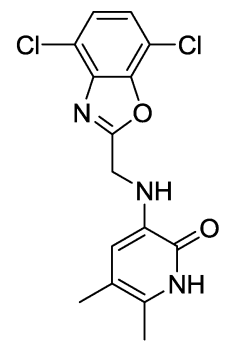

L-697,661<smiles>COC(=O)c1cccc2oc(-c3cccc4oc(-c5ccccc5O)nc34)nc12</smiles>

UK1

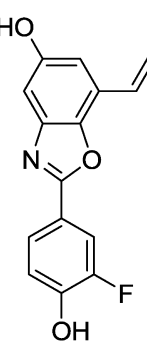

ERB-041
Figure 1. Examples of biologically active benzoxazoles.

The discovery of these types of compounds served as a basis for the development of new derivatives containing the benzoxazole structure. For example, benzoxazole derivatives have been used in disease treatments ${ }^{1}$ and have biological activities as antibiotic, ${ }^{2}$ antimycobacterial, ${ }^{3}$ antiparasitic, ${ }^{4}$ and antitumoral agents. ${ }^{5}$ For example, benoxaprofen is a potent anti-inflammatory agent. ${ }^{6}$

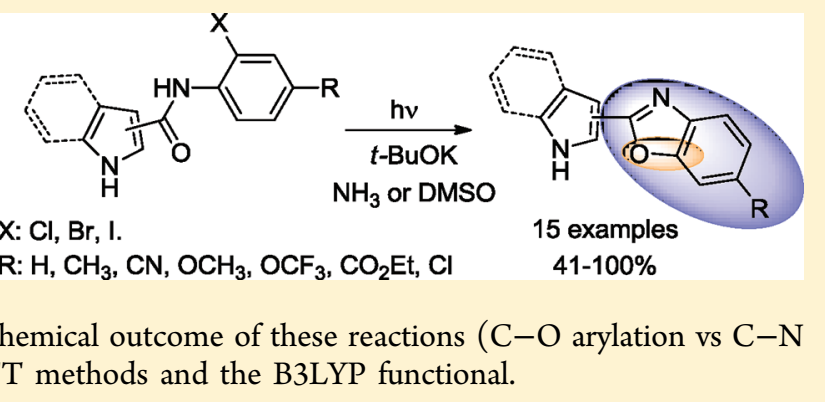

Benzoxazole L-697,661 was reported to inhibit the spread of HIV infection by $95 \%$ in MT4 cell culture. ${ }^{7}$ ERB-041 is used in the treatments of rheumatoid arthritis. ${ }^{8}$ CP 2289 is a ligand of the 5-HT3 receptor showing agonistic activities on the gastroenteric motility, ${ }^{9}$ and UK-1 is a structurally unique bisbenzoxazole (natural product) isolated from a strain of Streptomyces, which has been reported to exhibit anticancer activity. ${ }^{10}$

Compounds with a benzoxazole structure possess fluorescence properties and find application in electronic devices, ${ }^{11}$ sensors for metals, ${ }^{12}$ and photoluminescent dyes. ${ }^{13}$

The classical methods of synthesis used to obtain 2-arylbenzoxazole employ the use of 2-aminophenols as starting precursors (Scheme 1). Several synthetic strategies consist of coupling the 2-aminophenols with aromatic carboxylic acid or acid derivatives by dehydration, which can be generally catalyzed by strong acid, such as polyphosphoric acid, ${ }^{14}$ or by $p$-toluensulfonic acid under microwave irradiation. ${ }^{15}$ Another approach involves the condensation of aldehydes followed by oxidative cyclization conditions ${ }^{16}$ or by a bioenzymatic transformation ${ }^{17}$ (step a, Scheme 1). Oxidative cyclization requires the use of a stoichiometric amount of oxidant, and the further purification involves toxic workup procedures to remove the transition metals. In addition, these approaches are limited by the availability of the properly substituted 2-aminophenols.

Another methodology to furnish this type of heterocycle is via an aryne reaction using $\mathrm{N}$-(2-halophenyl)benzamide and potassium amide in liquid ammonia (step $\mathrm{b}$, Scheme 1$){ }^{18}$ From $\mathrm{N}$-(2-halophenyl)benzamide by intramolecular $\mathrm{O}$-arylation copper ${ }^{19}$ or iron-catalyzed ${ }^{20}$ reactions, 2-arylbenzoxazoles

Received: November 18, 2011

Published: December 22, 2011 
Scheme 1. 2-Arylbenzoxazoles Synthesis

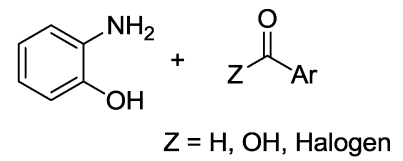

a)<smiles>[X]c1ccccc1NC(=O)[Al]</smiles>

b)<smiles>[Te]Cc1nc2ccccc2o1</smiles>

$\mathrm{X}=\mathrm{H}$ or halogen

c)

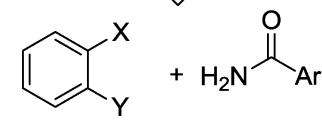

$X=Y=$ halogen

${ }^{a}$ Classical methods or bioenzymatic transformation. ${ }^{b} \mathrm{X}=$ halogen, $\mathrm{C}-\mathrm{O}$ bond formation by aryne mechanism, cross-coupling or photosubstitution; $\mathrm{X}=\mathrm{H}, \mathrm{C}-\mathrm{H}$ activation/cross-coupling. ${ }^{\mathrm{c}}-\mathrm{N} / \mathrm{C}-\mathrm{O}$ cross-coupling.

are obtained in very good yields (step b). Similar intramolecular $\mathrm{C}-\mathrm{O}$ bond formation by photostimulation of $\mathrm{N}$-(2halophenyl)benzamide in basic medium afforded the benzoxazole in low yield. ${ }^{21}$

Recently, bond formation through $\mathrm{C}-\mathrm{H}$ activation/crosscoupling approach using transition metal complexes has gained importance, as it obviates the need for prior activation steps. An efficient method of synthesis of functionalized benzoxazoles through $\mathrm{C}-\mathrm{H}$ activation was described, which used a copper(II)-catalyst (step b, Scheme $1, \mathrm{X}=\mathrm{H}){ }^{22}$ Recently, the synthesis by copper-catalyzed conversion of bisaryloxime ethers was reported. ${ }^{23}$ This reaction involves a cascade of $\mathrm{C}-\mathrm{H}$ functionalization and $\mathrm{C}-\mathrm{O}$ bond formation. The disadvantage of this method is the synthetic availability of the precursors, which requires many steps and purification.

Another possibility exists starting from 1,2-dihaloarenes and primary amides by intermolecular aryl-amide bond formation, followed by intramolecular aryl-oxygen coupling reactions catalyzed by copper (step c, Scheme 1). ${ }^{19 b, 24}$

The unimolecular radical nucleophilic substitution $\left(S_{\mathrm{RN}} 1\right)$ reaction is a synthetically useful process to mediate aromatic nucleophilic substitutions for the preparation of carbo- and heterocycles. $^{25}$ This reaction has been used to obtain oxindoles, ${ }^{26}$ benzothiazoles, ${ }^{27}$ aporphines, ${ }^{28}$ phenantridines, ${ }^{29}$ carbazoles, ${ }^{30}$ and carbolines. ${ }^{31}$ While anions derivatives from anilines, phenols, amides, and ketones were used as nucleophiles in intramolecular $S_{\mathrm{RN}} 1$ reactions, pyrrolyl and indolyl anions have not been exhaustively studied. ${ }^{32}$

By employing the intermolecular $S_{\mathrm{RN}} 1$ reaction, arylpyrroles and arylindoles were synthesized electrochemically by the reaction of pyrrolyl and indolyl anions with aryl halides in liquid ammonia. ${ }^{33}$ For pyrrolyl anion, $\mathrm{C}_{2}$ is more reactive $(50-70 \%)$ than $\mathrm{C}_{3}(3-15 \%)$ toward the coupling reaction. In this case, mono- and diarylation products were formed. On the other hand, for the indolyl anion, only the $C$-arylation product substitution at $\mathrm{C}_{3}$ product was observed. ${ }^{33 \mathrm{~b}}$

Herein, we propose the use of these types of anions to study reactivity and regiochemistry in an intramolecular nucleophilic substitution in photostimulated reactions. To carry this out, we synthesized precursors such as pyrrole 2-carboxamides (1) or indole 2- and 3-carboxamides (2 and 3), where the leaving group and nucleophilic center are in the same molecule in an appropriate position (Scheme 2). In $\mathbf{1}$ or $\mathbf{2}$ there are three main

Scheme 2. Intramolecular Arylation of Anions from 2-Pyrrole Carboxamides (1), 2-Indole Carboxamides (2) or 3-Indole Carboxamides (3)<smiles>[R]c1ccc2[nH]c(=O)c3cc4ccccc4n3c2c1</smiles>

$\mathrm{C}_{3}$-substitution $\mathrm{N}$-substitution $\quad \mathrm{C}_{2}$-substitution<smiles>[R]c1ccc(NC(=O)c2cc([R])ccc2NC(=O)c2c(C)[nH]c3ccccc23)c([X])c1</smiles>

different nucleophilic centers: (i) $\mathrm{C}_{3}$, (ii) the nitrogen in the pyrrole or indole ring, and (iii) the $\mathrm{O}$ - of the amide function. We expected to obtain the $C$-substitution product, but the $\mathrm{O}$-substitution was the only product obtained, resulting in the synthesis of a new family of 2-(1H-pyrrol-2-yl)benzo[d] oxazoles (4) or 2-(1H-indol-2-yl)benzo[d] oxazoles (5). In a similar manner, 3 has two main nucleophilic centers: (i) $\mathrm{C}_{2}$ in the indole ring and (ii) the $\mathrm{O}$ - of the amide moiety; only $\mathrm{O}$-substitution product (6) was afforded

In view of the importance and applicability of 2-pyrrolyl and indolyl benzoxazoles, we report here a practical and efficient route to obtain these heterocycles from pyrrole and indole carboxamides. As a first step, the synthetic strategy involves an amidation reaction of different 2-haloanilines with 2-carboxylic acid of pyrrole and 2- or 3-carboxylic acids of indole followed by a photostimulated reaction in liquid ammonia $\left(\mathrm{NH}_{3(1)}\right)$ or DMSO as solvents.

Furthermore, we demonstrated mechanistic probes and computational studies that suggest that these reactions occur by a photoinduced electron transfer (ET).

\section{RESULTS AND DISCUSSION}

Pyrrole and indole carboxamides derivatives 1, 2, and 3 were obtained by reaction of 2-carboxylic acid of pyrrole and 2- or 3carboxylic acid of indole with 2-haloanilines, following previously reported methods ${ }^{19 \mathrm{~d}, 34}$ (Scheme 3 ). Within this approach, the acyl 
Scheme 3. Synthesis of Amide Derivatives from 2-Carboxylic Acid of Pyrrole and 2- or 3-Carboxylic Acid of Indole

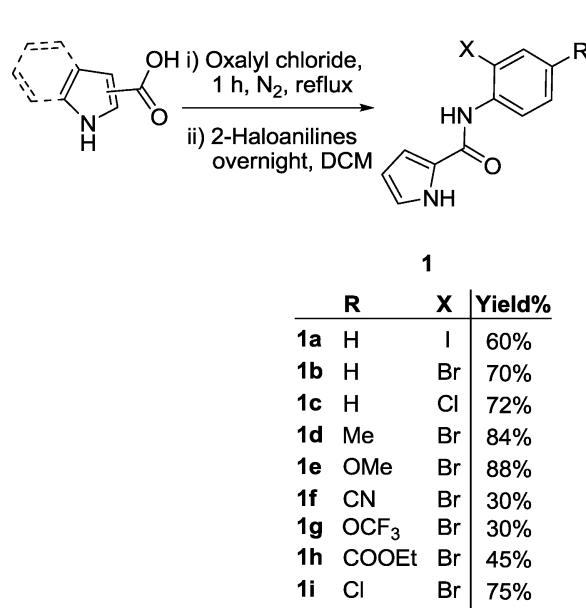

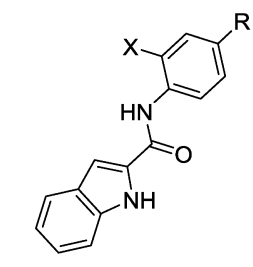

2

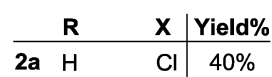

\begin{tabular}{lll|l} 
2a & $\mathrm{H}$ & $\mathrm{Cl}$ & $40 \%$ \\
2b & $\mathrm{Me}$ & $\mathrm{Br}$ & $63 \%$
\end{tabular}

2c $\mathrm{OMe} \quad \mathrm{Br} \quad 86 \%$

2d $\mathrm{OCF}_{3} \mathrm{Br} \quad 10 \%$

2e COOEt $\mathrm{Br} \quad 45 \%$

$2 \mathrm{Cl} \quad \mathrm{Br} 52 \%$

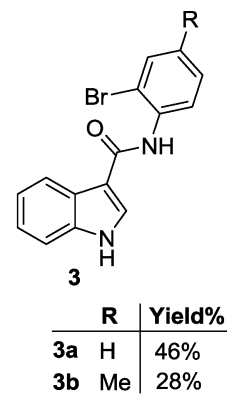

\begin{tabular}{ll|l} 
3b & $\mathrm{Me}$ & $28 \%$
\end{tabular} chloride was obtained and used without purification in a onepot procedure.

The synthesis of 2-pyrrolyl benzoxazoles was initially studied with $\mathrm{N}$-(2-iodophenyl)-1H-pyrrole-2-carboxamide (1a) as a model substrate. When 1a reacted under photostimulation conditions with 2 equiv of $t$ - $\mathrm{BuOK}$ as a base, 2 -(1H-pyrrol-2-yl)benzo $[d]$ oxazole $4 \mathrm{a}$ was obtained in $75 \%$ yield (liquid ammonia) and in $73 \%$ yield (DMSO), following $2 \mathrm{~h}$ of irradiation (eq 1 ; entries 1 and 3, Table 1). None of the reduction product $7 \mathbf{a}$ was found. $^{32,35}$ Complete conversion of $\mathbf{1 a}$ was accomplished by extending the reaction time and afforded the ring closure products $4 \mathbf{a}$ in quantitative yield (liquid ammonia) and in $83 \%$ yield (DMSO) (entries 2 and 4, Table 1), respectively. ${ }^{36}$

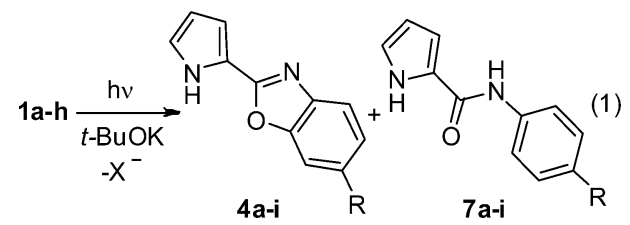

The reaction was shown not occur in the dark (entry 5, Table 1), which would rule out an aryne or other polar mechanism. If a good electron acceptor is added, such $p$-dinitrobenzene ( $p$-DNB), the product of the reaction is not observed, which could be attributed to inhibiting electron transfer events ${ }^{25}$ (entry 6, Table 1). Besides, the use of $20 \mathrm{~mol} \%$ of $p$-DNB results in complete inhibition of the substitution reaction, which suggests the involvement of a chain mechanism.

Under the same conditions, substrate la was more reactive than $\mathbf{1 b}$ and $\mathbf{1 c}$ (entries 4, 9, and 12, Table 1). For substrates $\mathbf{1 b}$ and $\mathbf{1 c}$, longer reaction times and an excess of base were required to achieve complete conversion (entries 7-13, Table 1). However, the reactions of $\mathbf{1 b}$ and $\mathbf{1 c}$ demonstrate that the reaction was useful for both chlorine- and brominecontaining substrates. These results are in agreement with those of the order of reactivity of the different halogens in photostimulated $\mathrm{S}_{\mathrm{RN}} 1$ reactions $(\mathrm{I}>\mathrm{Br}>\mathrm{Cl}){ }^{25}$ In some cases, reduced product $7 \mathrm{a}$ was detected (entries 8 and 10 , Table 1 ), which also indicates that aryl radicals are intermediates and that

Table 1. Photostimulated Reactions of Substrates $1 \mathrm{a}-\mathrm{c}$ and $1 \mathrm{i}^{\mathrm{a}}$

\begin{tabular}{|c|c|c|c|c|c|c|}
\hline entry & substrate $(\%)^{b}$ & solvent (conditions) & base (equiv) & time $(\mathrm{h})$ & $4 \mathbf{a}(\%)^{c}$ & $\mathrm{X}(\%)^{d}$ \\
\hline 1 & 1a $(25)$ & $\mathrm{NH}_{3(1)}$ & 2 & 2 & 75 & 80 \\
\hline 2 & 1a & $\mathrm{NH}_{3(1)}$ & 2 & 3 & 100 & 100 \\
\hline 3 & 1a $(27)$ & DMSO & 2 & 2 & 73 & 75 \\
\hline 4 & 1a & DMSO & 2 & 3 & 83 & 100 \\
\hline 5 & 1a $(95)^{e}$ & DMSO (dark) & 2 & 3 & - & $<5$ \\
\hline 6 & 1a $(>99)$ & DMSO (20 mol $\% p$-DNB) & 2 & 3 & - & $<5$ \\
\hline 7 & $\mathbf{l b}(20)$ & $\mathrm{NH}_{3(1)}$ & 4 & 3 & 35 & 72 \\
\hline 8 & $1 b$ & $\mathrm{NH}_{3(1)}$ & 4 & 4 & $60^{f}$ & 91 \\
\hline 9 & $1 \mathbf{b}^{g}$ & DMSO & 2 & 3 & 62 & 64 \\
\hline 10 & $1 b$ & DMSO & 4 & 3 & $72^{h}$ & 89 \\
\hline 11 & $1 \mathrm{c}$ & $\mathrm{NH}_{3(1)}$ & 4 & 5 & 44 & 79 \\
\hline 12 & $1 c^{g}$ & DMSO & 2 & 3 & 48 & 47 \\
\hline 13 & 1c & DMSO & 4 & 5 & 57 & 70 \\
\hline 14 & $1 c^{g}$ & DMSO (34 mol $\% p$-DNB) & 2 & 3 & 11 & 23 \\
\hline 15 & $1 i^{g}$ & DMSO & 4 & 3 & $6+4 i(44)$ & $90^{i}$ \\
\hline 16 & $1 \mathrm{i}$ & $\mathrm{NH}_{3(1)}$ & 4 & 3 & 39 & $96\left(\mathrm{Br}^{-}\right) 78\left(\mathrm{Cr}^{-}\right)$ \\
\hline
\end{tabular}

${ }^{a_{T}}$ The reactions were run in $200 \mathrm{~mL}$ of liquid ammonia or $4 \mathrm{~mL}$ of DMSO, with 1 equiv of substrate $(0.25 \mathrm{mmol})$ and $t$-BuOK as base. Irradiation was conducted in a photochemical reactor equipped with two HPI-T $400 \mathrm{~W}$ lamps (cooled with water). ${ }^{b}$ Substrate recovered was determined by GC (internal standard method). ${ }^{c}$ Yields were determined by GC (internal standard method). ${ }^{d}$ Halide ions were determined potentiometrically. ${ }^{e}$ Isolated yield. ${ }_{8 \%} \%$ of reduced product $7 \mathbf{a}$, isolated yield. ${ }^{g}$ Substrate was detected but not quantified. ${ }^{h} 9 \%$ of reduced product $7 \mathbf{a}$, isolated yield. ${ }^{i}$ Only one equivalent point was detected. 
no polar reactions are involved. The photostimulated reaction of $1 \mathrm{c}$ was inhibited in presence of $p$-DNB (entry 14, Table 1), and only $11 \%$ yield of $4 \mathbf{a}$ was obtained; a similar behavior for the substrate la was observed.

The pyrrole carboxamides 1 bear two hydrogens that can be ionized under basic reaction conditions, the $\mathrm{N}-\mathrm{H}$ of the pyrrolyl moiety $\left(\mathrm{N}^{1}\right)$ and the $\mathrm{N}-\mathrm{H}$ of the carboxamide moiety $\left(\mathrm{N}^{2}\right)$ (Scheme 4). The $\mathrm{p} K_{\mathrm{a}} \mathrm{s}$ for these compounds are unknown for liquid ammonia or DMSO. ${ }^{37}$ To gain further knowledge into the type of anion actually formed, computational calculations were performed for $\mathbf{1} \mathbf{b}$ to estimate the $\mathrm{p} K_{\mathrm{a}}$ of each anion. Using a DFT method with polarized continuum model (PCM) to evaluate the effect of the solvent, ${ }^{38}$ it was determined that the pyrrole anion $\mathbf{1}-\mathbf{N}^{\mathbf{1}}$ is energetically more stable than the amide anion $1-\mathrm{N}^{2}$ by $2.1 \mathrm{kcal} / \mathrm{mol}^{39}$

Scheme 4. Ionization of Pyrrole Carboxamide $1 \mathrm{~b}$ in the Basic Reaction Conditions

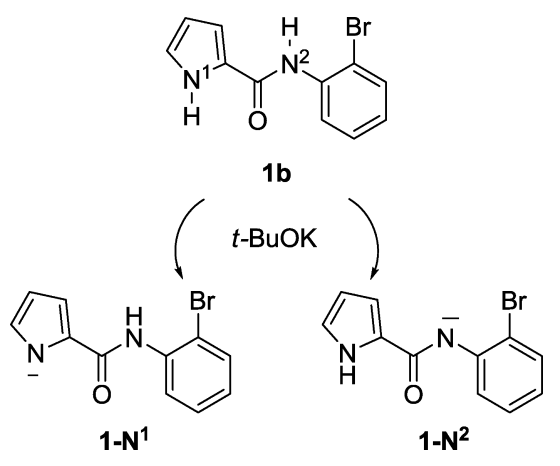

To evaluate the importance of the pyrrolyl moiety in the reaction, the photostimulated reaction of $\mathrm{N}$-(2-bromophenyl)benzamide (8) with an excess of $t$-BuOK in DMSO was performed (same experimental conditions as previously used in Table 1), which gave no reaction at all, recovering the substrate (eq 2). When 1.13 equiv of $\mathrm{Ph}_{2} \mathrm{P}^{-}$ions were used as electron donors, reduced product $N$-phenylbenzamide 9 was obtained in $52 \%$ yield. These results indicate that the pyrrolyl moiety is important not only to the initiation of the reaction but also for the cyclization step.

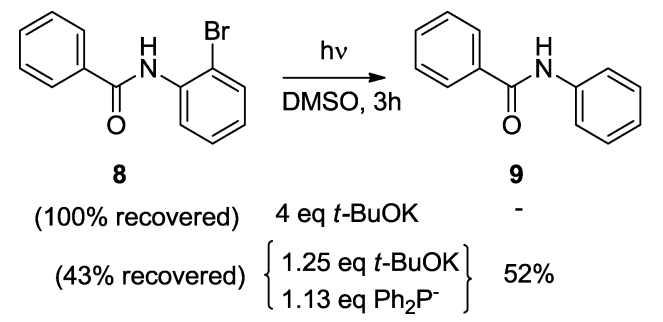

On the basis of the present and previous results, an $S_{\mathrm{RN}} 1$ mechanism was proposed to be operative in the reaction described here (eqs 3-6). Substrate 1 forms the anion $\mathbf{1}^{-}$in the basic reaction conditions (eq 3); under irradiation, it receives an electron from an adequate electron source. ${ }^{40}$ After fragmentation of the $\mathrm{C}-\mathrm{X}$ bond, the distonic radical anion 10 is formed (eq 4); the aryl radical 10 then couples at the oxygen to give the conjugated radical anion 11. The radical anion 11 affords the final product 4 by ET and is followed by deprotonation/protonation events (eq 5). With some substrates, the radical anion $\mathbf{1 0}$ can also be reduced by hydrogen abstraction and protonation to yield 7 (eq 6).

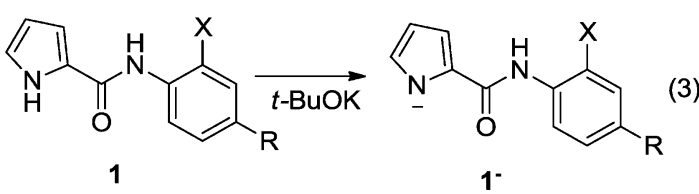<smiles>[R]c1ccc(NC(=O)c2cccn2CC)c(CC)c1</smiles><smiles>[R]c1ccc2c(c1)O/C(=C1\Oc3cc([R])ccc3[C@@H]1C)N2</smiles><smiles>[R]c1ccc(NC(=O)c2ccc[nH]2)c([Z])c1</smiles>

Other results that support the involvement of radical anions as an intermediate is the reaction of the precursor $\mathbf{1 i}$ bearing two leaving groups. In the photostimulated reaction of anion $\mathbf{1 i}^{-}$in DMSO, the product $4 \mathbf{i}$ with retention of chlorine was obtained as the major product, and a low amount of $\mathbf{4 a}$ was obtained without retention of chlorine (entry 15, Table 1). When liquid ammonia was used as solvent, only product $\mathbf{4 a}$ was achieved (entry 16, Table 1). Competition between intermolecular electron transfer $\left(\mathrm{ET}_{\text {inter }}\right)$ and an intramolecular electron transfer $\left(\mathrm{ET}_{\text {intra }}\right)$ from a radical anion intermediate 11i may account for this behavior (Scheme 5). ${ }^{25}$ In this system, we

Scheme 5. Competition $\mathrm{ET}_{\text {inter }}$ and $\mathrm{ET}_{\text {intra }}$ for Intermediate $11 \mathrm{i}$

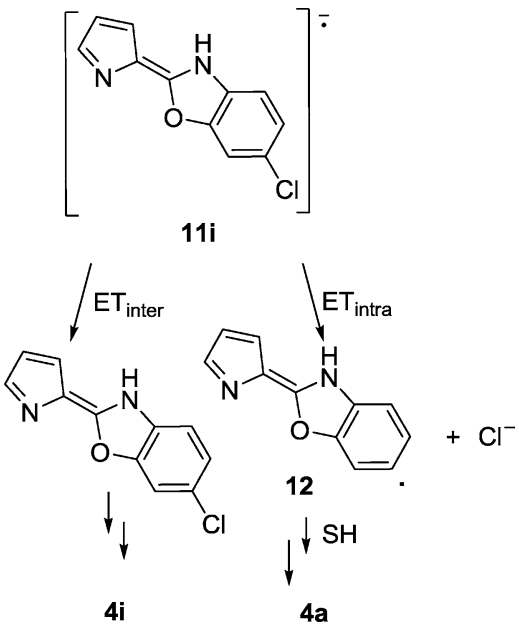

propose that once the conjugated radical anion $11 \mathrm{i}$ is formed, it can transfer its extra electron to the substrate $\left(\mathrm{ET}_{\text {inter }}\right)$, and in this case, the more stable tautomer $\mathbf{4} \mathbf{i}$ with retention of halogen is formed. Alternatively, the $\mathrm{ET}_{\text {intra }}$ to the $\mathrm{C}-\mathrm{Cl}$ bond results in fragmentation to form a radical $\mathbf{1 2}$ and ultimately leads to $\mathbf{4 a}$. On the basis of the concentration difference of anion $\mathbf{1 i}^{-}$, which 
is greater in DMSO, the $\mathrm{ET}_{\text {inter }}$ is faster than the $\mathrm{ET}_{\text {intra }}$ process, and a product with retention of the second halogen is obtained in this solvent.

It has been established that anions from anilines and phenols react by an intramolecular $S_{\mathrm{RN}} 1$ mechanism in photostimulated reactions. ${ }^{25,28-31}$ Some examples show where aryl radicals can react with an oxygen nucleophile in intramolecular reactions. ${ }^{41}$ The results of the computational studies indicated that conformations of the distonic radical anion are important in determining the regiochemistry of the coupling. ${ }^{29}$ We decided to perform a detailed computational study aimed at determining which electronic and/or geometric factor was responsible for establishing the preferred regiochemistry.

The system was investigated using computational modeling with the DFT methodology and the B3LYP functional. ${ }^{38}$ The anion 1-N $\mathbf{N}^{1}$ exhibits various conformers; the more stable conformer has a planar conformation (Figure S1 in the Supporting Information). This conformer provides, after dissociative electron transfer (DET), a distonic radical anion 10a. This intermediate does not possess an appropriate geometry to afford C-, N-, or O-coupling, so internal rotations were needed to give any of the three possible coupling reactions (Scheme 6 and 7). ${ }^{42}$

Scheme 6. Main Conformers for Radical Anion 10, C-O Coupling $^{a}$
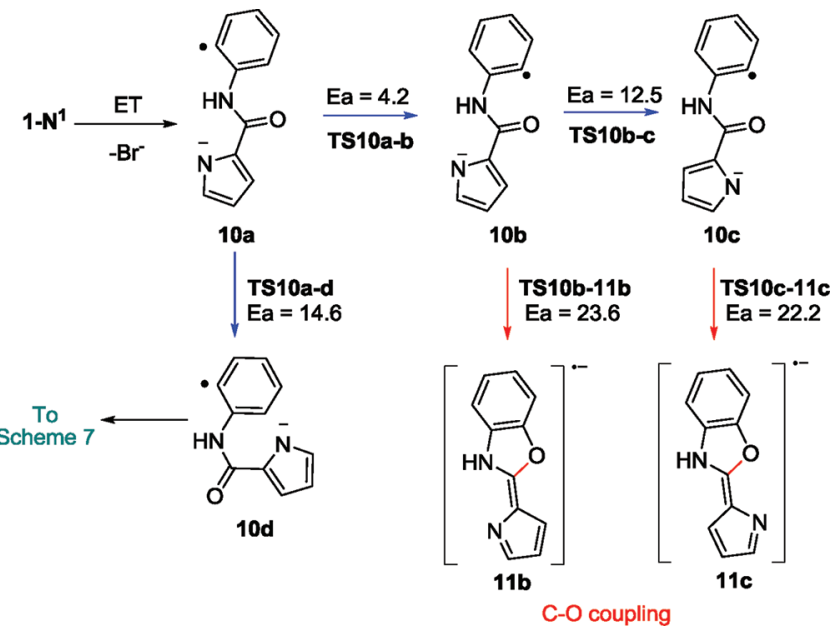

${ }^{a}$ Energies are in $\mathrm{kcal} \mathrm{mol}^{-1}$.

Conformer 10a gives, after internal rotation $\left(\mathrm{Ea}_{\mathrm{rot}}=4.2 \mathrm{kcal} / \mathrm{mol}\right)$, $10 \mathrm{~b}$, which affords conjugated radical anion $11 \mathrm{~b}$ with a high calculated activation energy of $23.6 \mathrm{kcal} / \mathrm{mol}$. On the other hand, internal rotation from $10 \mathrm{a}\left(\mathrm{Ea}_{\text {rot }}=14.6 \mathrm{kcal} / \mathrm{mol}\right)$ is required (Scheme 6) to give $\mathrm{C}-\mathrm{N}\left(\mathrm{Ea}_{\mathrm{C}-\mathrm{N}}=2.7 \mathrm{kcal} / \mathrm{mol}\right)$ or $\mathrm{C}-\mathrm{C}$ coupling $\left(\mathrm{Ea}_{\mathrm{C}-\mathrm{C}}=1.9 \mathrm{kcal} / \mathrm{mol}\right)$ with a lower barrier (Scheme 7).

A similar analysis was performed for the radical anion derived from $\mathbf{1 - N ^ { 2 }}$ and the anion of $\mathbf{8}$, which also gives high calculated activation energies for the $\mathrm{C}-\mathrm{O}$ coupling (eqs 7 and 8).

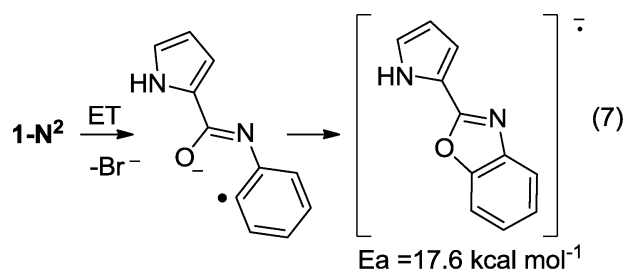

Scheme 7. Main Conformers for Radical Anion 11, C-C and C-N Coupling ${ }^{a}$

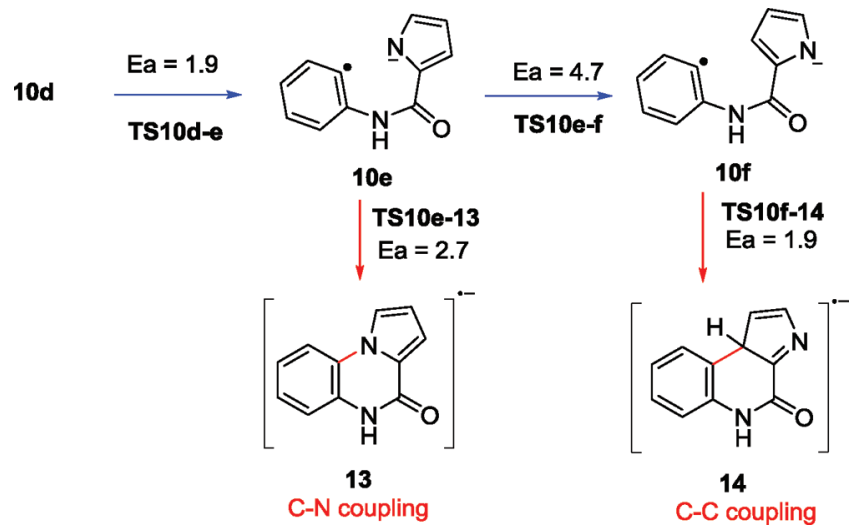

${ }^{a}$ Energies are in $\mathrm{kcal} \mathrm{mol}^{-1}$.

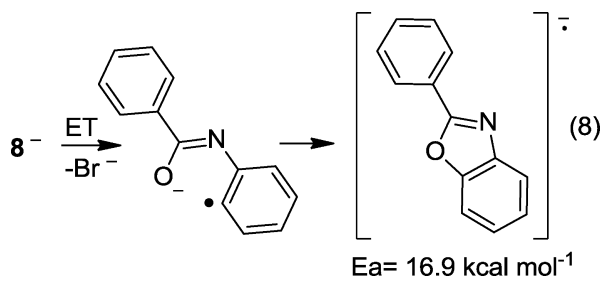

The results illustrated in eq 8 agree with the experimental results because 8 only provided the reduced product 9 when initiation was achieved by the presence of $\mathrm{Ph}_{2} \mathrm{P}^{-}$ions (eq 2). However, the proposed mechanism fails to explain the experimental results in the case of compound $\mathbf{1} \mathbf{b}$. There does not exist an apparent reason to explain why the calculation methodology is not adequate; DFT functionals have been used to study different steps of $S_{\mathrm{RN}} 1$ reaction. ${ }^{29,43}$ An alternative mechanism could be operant, which must have common characteristics with the $S_{\mathrm{RN}} 1$ mechanism, like ET events and chain process, but having a different order of steps.

The scope of photostimulated reactions for the synthesis of various 6-substituted 2-(pyrrol-2-yl)benzoxazoles (4d-h) were explored. The results of the photostimulated reaction of 2-pyrrole carboxamides $\mathbf{1 d - h}$ in liquid ammonia and DMSO, in the presence of excess $t$-BuOK, are presented in Table 2 (eq 1).

Under these reaction conditions, very good to excellent yields (78-91\%) of 6-substituted 2-(pyrrol-2-yl)benzoxazole $\mathbf{4 d}-\mathbf{h}$ are obtained; many substituents, such as electron-releasing groups $(\mathrm{Me}, \mathrm{OMe})$ and electron-withdrawing groups $\left(\mathrm{CN}, \mathrm{OCF}_{3}\right.$, $\mathrm{CO}_{2} \mathrm{Et}$ ), were compatible with this reaction.

Therefore, substrates $\mathbf{2} \mathbf{a}-\mathbf{f}$ and $\mathbf{3 a}, \mathbf{b}$ were studied under photostimulated conditions, affording good to excellent yields of 2-(indol-2-yl) $(\mathbf{5 a - f})$ and 2-(indol-3-yl)benzoxazoles $(\mathbf{6 a}, \mathbf{b})$ (Scheme 8). With a similar behavior as 2-pyrrole carboxamides, many substituents are compatible with this reaction. Results are shown in Table 3.

We decided to study the regiochemistry of the reaction in a new system, changing the nature of the bridge. 2-Iodophenyl- $1 \mathrm{H}$ indole-2-carboxylate (17), which has an ester function as a bridge connecting the nucleophilic center and the leaving group, was synthesized. Ester derivative 17 was obtained by reaction of 2-carboxylic acid indole and 2-iodophenol, following reported methods $^{19 \mathrm{~d}}$ (eq 9). When 17 reacted with 2.5 equiv of $t$-BuOK 
Table 2. Synthesis of 6-Substituted 2-(1H-Pyrrol-2-yl)benzo$[d]$ oxazoles by Photostimulated Reactions ${ }^{a}$

\begin{tabular}{lclclll} 
entry & substrate & solvent & $\begin{array}{c}\text { base } \\
\text { (equiv) }\end{array}$ & $\begin{array}{c}\text { time } \\
(\mathrm{h})\end{array}$ & \multicolumn{1}{c}{ yield $(\%)^{b}$} & $\begin{array}{c}\mathrm{X} \\
(\%)^{c}\end{array}$ \\
\hline 1 & $\mathbf{1 d}$ & $\mathrm{NH}_{3(1)}$ & 2.5 & 3 & $\mathbf{4 d}(59)+7 \mathbf{d}(36)$ & 100 \\
2 & $\mathbf{1 d}$ & $\mathrm{DMSO}$ & 4 & 3 & $\mathbf{4 d}(85)$ & 100 \\
3 & $\mathbf{1 e}$ & $\mathrm{NH}_{3(1)}$ & 10 & 4.5 & $\mathbf{4 e}(40)+7 \mathbf{e}(53)$ & 100 \\
4 & $\mathbf{1 e}$ & $\mathrm{DMSO}$ & 8 & 4.5 & $\mathbf{4 e}(82)+7 \mathbf{e}(14)$ & 100 \\
5 & $\mathbf{1 f}$ & $\mathrm{NH}_{3(1)}$ & 2.5 & 3 & $\mathbf{4 f}(78)^{d}$ & 82 \\
6 & $\mathbf{1 f}$ & $\mathrm{DMSO}^{d}$ & 2.5 & 3 & $\mathbf{4 f}(66)^{d}$ & 72 \\
7 & $\mathbf{1 g}$ & $\mathrm{NH}_{3(1)}$ & 4 & 3 & $\mathbf{4 g}(91)^{e}$ & 99 \\
8 & $\mathbf{1 g}$ & $\mathrm{DMSO}^{e}$ & 2.5 & 3 & $\mathbf{4 g}(54)^{e}$ & 63 \\
$9^{f}$ & $\mathbf{1 h}$ & $\mathrm{NH}_{3(1)}$ & 4 & 3 & $\mathbf{4 h}(26)$ & 85 \\
$10^{f}$ & $\mathbf{1 h}$ & $\mathrm{DMSO}$ & 4 & 3 & $\mathbf{4 h}(88)$ & 91
\end{tabular}

${ }^{a_{T}}$ The reactions were run in $200 \mathrm{~mL}$ of liquid ammonia or $4 \mathrm{~mL}$ of DMSO, with 1 equiv of substrate $(0.25 \mathrm{mmol})$ and $t$ - $\mathrm{BuOK}$ as base. Irradiation was conducted in a photochemical reactor equipped with two HPI-T $400 \mathrm{~W}$ lamps (cooled with water). ${ }^{b}$ Yields were determined by ${ }^{1} \mathrm{H}$ NMR (internal standard method). ${ }^{c}$ Halide ions were determined potentiometrically. ${ }^{d}$ Isolated yield. ${ }^{e}$ Yields were determined by GC (internal standard method). ${ }^{f_{\text {The }}}$ product was obtained as its acid form. After the photostimulated reaction, the acid was esterified and quantified as the ester.

Scheme 8. Photostimulated Reaction of Indole 2- and 3-Carboxamides
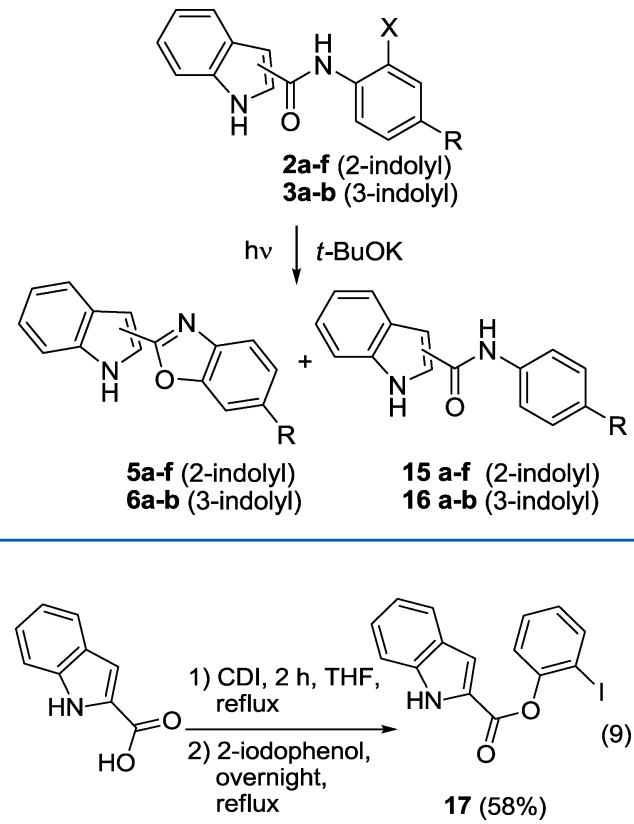

under photostimulation in liquid ammonia as the solvent, only the $C$-arylation product, chromeno[3,4-b]indol-6(7H)-one (18), was obtained in $54 \%$ yield (eq 10; entry 1 , Table 4 ). When the reaction was carried out in DMSO, 18 was found in $19 \%$ yield (entry 2, Table 4). To reduce the decomposition of the starting material, 2-naphtoxide ion was used instead of $t$ - $\mathrm{BuOK}$ as an entrainment reagent. In this case, a similar behavior was observed in liquid ammonia, and the yield of the cyclization product was found to increase in DMSO (entries 3 and 4, Table 4).

In this case, the photostimulated reaction of $\mathbf{1 7}$ afforded the $\mathrm{C}-\mathrm{C}$ arylation product 18 , and the regiochemistry was according to expectations for an $S_{\mathrm{RN}} 1$ reaction. This indicated that the nature of the bridge has a high impact on the coupling step.<smiles>O=c1oc2ccccc2c2c1[nH]c1ccccc12</smiles>

\section{CONCLUSIONS}

We develop a simple and efficient synthetic strategy to obtain 2-pyrrolyl and indolyl benzoxazole derivatives by a photostimulated process. This approach does not involve the use of transition metals or drastic reaction conditions, and a variety of substituents are tolerated under the reaction conditions employed. In addition, we have shown that (i) the reaction only occurs under photostimulation and (ii) the photostimulated reaction was inhibited by $p$-DNB, which suggest that there are probably electron transfer events.

From the computational results, the anion derivative from the heterocycle is involved in the reaction. According to the experimental results, an $S_{\mathrm{RN}} 1$ mechanism is consistent with the formation of the benzoxazol heterocycle; however, this fact was not supported by quantum calculations.

The nature of the bridge in the precursor is important for the regiochemistry of the reaction; in the case of the amide derivatives, only $\mathrm{O}$-substitution was achieved, whereas when an ester derivative was employed as substrate, $C$-substitution was observed.

\section{EXPERIMENTAL SECTION}

Computational Procedures. All calculations were performed with the Gaussian09 program. ${ }^{44}$ First, the most stable conformers of $\mathbf{1 b}$ and the anions $\mathbf{1 - \mathbf { N } ^ { 1 }}$ and $\mathbf{1 - \mathbf { N } ^ { 2 }}$ were evaluated through an AM1 conformational search by scanning the two or three main torsion angles. The conformers thus obtained were then refined with complete geometry optimization within the B3LYP ${ }^{45}$ DFT functional with the $6-31+\mathrm{G}^{*}$ basis set.

The radical anions that formed once the halides are released were fully optimized with the same functional and the $6-31+G^{*}$ basis set. The geometries thus found were used as starting points for the evaluation of the potential surface of the different reaction steps with the same functional and the latter basis set and the reaction coordinate approach.

The effect of the solvent was evaluated for all of the DFT calculations through Tomasi's polarized continuum model (PCM), ${ }^{46}$ as implemented in Gaussian09, using methanol and complete geometry optimization. The characterization of stationary points was done by Hessian matrix calculations. The energy informed for TSs, anions, and radical anions includes zero-point corrections.

General Methods. ${ }^{1} \mathrm{H}$ NMR $(400.16 \mathrm{MHz}),{ }^{13} \mathrm{C}$ NMR (100.62 $\mathrm{MHz})$, and ${ }^{19} \mathrm{~F}$ NMR $(376.50 \mathrm{MHz})$ were conducted on a high resolution spectrometer $400 \mathrm{MHz}$ in $\mathrm{CDCl}_{3}$, acetone- $d_{6}$, and DMSO$d_{6}$ as a solvent. Coupling constants are given in $\mathrm{Hz}$, and chemical shifts are reported in ppm. Data are reported as follows: chemical shift, integration, multiplicity $(\mathrm{s}=$ singlet, $\mathrm{s}$ br $=$ broad singlet, $\mathrm{d}=$ doublet, $\mathrm{t}=$ triplet, $\mathrm{dd}=$ double doublet, $\mathrm{dt}=$ double triplet, $\mathrm{ddd}=$ double double doublet, $\mathrm{m}=$ multiplet), and coupling constants $(J)$. Gas chromatographic (GC) analyses were performed on an instrument with a flame ionization detector equipped with a VF-5ms column $(30 \mathrm{~m} \times 0.25 \mathrm{~mm} \times 0.25 \mu \mathrm{m})$. GC-MS analyses were carried out on a GC-MS equipped with a quadrupole detector and a VF-5ms column $(30 \mathrm{~m} \times 0.25 \mathrm{~mm} \times 0.25 \mu \mathrm{m})$. High resolution mass spectra were performed in a MS/MS instrument in pure products. These data were 
Table 3. Synthesis of 6-Substituted 2-(1H-Indol-2-yl)benzo[d]oxazoles (5a-f) and 2-(1H-Indol-3-yl)benzo[d] oxazoles $(6 a-b)$ by Photostimulated Reactions ${ }^{a}$

\begin{tabular}{|c|c|c|c|c|c|c|}
\hline entry & substrate & solvent (conditions) & base (equiv) & time $(\mathrm{h})$ & yield $(\%)^{b}$ & $X^{-}(\%)^{c}$ \\
\hline 1 & $2 a$ & $\mathrm{NH}_{3(1)}$ & 2.5 & 3 & $5 \mathbf{a}(85)^{d}$ & 100 \\
\hline 2 & $2 a$ & DMSO & 2.5 & 3 & $5 \mathbf{a}(94)^{d}$ & 100 \\
\hline 3 & $2 b$ & $\mathrm{NH}_{3(1)}$ & 2.5 & 3 & $5 b(60)$ & 80 \\
\hline 4 & $2 b$ & DMSO & 2.5 & 3 & $\mathbf{s b}(86)$ & 100 \\
\hline 5 & $2 c$ & $\mathrm{NH}_{3(1)}$ & 8 & 4.5 & $5 c(74)$ & 93 \\
\hline 6 & $2 c$ & DMSO & 8 & 4.5 & $5 c(34) \mathbf{1 5 c}(30)$ & 100 \\
\hline $7^{e}$ & $2 c$ & DMSO (dark) & 8 & 4.5 & $5 c(-)$ & $<7$ \\
\hline 8 & $2 d$ & $\mathrm{NH}_{3(1)}$ & 4 & 3 & $\mathbf{5 d}(75)^{f}$ & 88 \\
\hline 9 & $2 d$ & DMSO & 4 & 3 & 5d $(19)^{f}$ & 70 \\
\hline 10 & $2 \mathrm{e}$ & $\mathrm{NH}_{3(1)}$ & 4 & 6 & 5e $(42)^{g}$ & 100 \\
\hline 11 & $2 \mathrm{e}$ & DMSO & 4 & 6 & 5e $(19)^{g}$ & 82 \\
\hline 12 & $2 f$ & $\mathrm{NH}_{3(1)}$ & 4 & 3 & $5 \mathbf{a}(32)^{d}$ & $75\left(\mathrm{Br}^{-}\right) 61\left(\mathrm{C}^{-}\right)$ \\
\hline 13 & $2 f$ & DMSO & 4 & 3 & $5 f(6) 5 a(16)$ & $79\left(\mathrm{Br}^{-}\right) 44\left(\mathrm{Cl}^{-}\right)$ \\
\hline 14 & $3 a$ & $\mathrm{NH}_{3(1)}$ & 4 & 3 & 6a (41) 16a (25) & \\
\hline 15 & $3 a$ & DMSO & 4 & 3 & 6a $(66)$ & 84 \\
\hline 16 & $3 \mathbf{b}$ & DMSO & 4 & 3 & $\mathbf{6 b}(80)^{f}$ & 93 \\
\hline
\end{tabular}

${ }^{a}$ The reactions were run in $200 \mathrm{~mL}$ of liquid ammonia or $4 \mathrm{~mL}$ of DMSO, with 1 equiv of substrate $(0.25 \mathrm{mmol})$ and $t$-BuOK as base. Irradiation was conducted in a photochemical reactor equipped with two HPI-T $400 \mathrm{~W}$ lamps (water refrigerated). ${ }^{b}$ Yields were determined by ${ }^{1} \mathrm{H}$ NMR (internal standard method). ${ }^{c}$ Halide anions were determined potentiometrically. ${ }^{d}$ Yields were determined by GC (internal standard method). ${ }^{e}$ The substrate was recovered almost quantitatively. ${ }^{f}$ Isolated yields. ${ }^{g}$ The product was obtained as its acid form. After the photostimulated reaction, the acid was esterified and quantified as the ester. ${ }^{h}$ The product 16 a was not isolated but detected by GC-MS and quantified assuming the same response as 6 .

\section{Table 4. Photostimulated Reactions of $17^{a}$}

$\begin{array}{clcccc}\text { entry } & \text { solvent } & \text { base (equiv) } & \text { 2-naphtol (equiv) } & \mathbf{1 8}(\%)^{b} & \Gamma(\%)^{c} \\ 1 & \mathrm{NH}_{3(1)} & 2.5 & & 54 & 85 \\ 2 & \mathrm{DMSO} & 2.5 & & 19 & 46 \\ 3 & \mathrm{NH}_{3(1)} & 3 & 2 & 48^{d} & 60 \\ 4 & \mathrm{DMSO} & 5 & 4 & 47 & 57\end{array}$

${ }^{a}$ The reactions were run in $200 \mathrm{~mL}$ of liquid ammonia or $4 \mathrm{~mL}$ of DMSO, with 1 equiv. of $17(0.25 \mathrm{mmol})$ and $t$-BuOK as base. Irradiation $(2.5 \mathrm{~h})$ was conducted in a photochemical reactor equipped with two HPI-T $400 \mathrm{~W}$ lamps (cooled with water). ${ }^{b}$ Yields were determined by GC (internal standard method). ${ }^{c}$ Halide ions were determined potentiometrically. ${ }^{d}$ Isolated yield.

obtained by ESI or APPI mode ionization and TOF detection. Melting points were performed with an electrical instrument and are uncorrected. Irradiation was conducted in a reactor equipped with two HPI-T $400 \mathrm{~W}$ lamps (cooled with water). The maxima of emission of the lamps used are 380-390, 420, 460, 560, and $600 \mathrm{~nm}^{47}$ Potentiometric titration of halide ions was performed in a $\mathrm{pH}$-meter using an $\mathrm{Ag} / \mathrm{Ag}^{+}$electrode. Quantification by $\mathrm{GC}$ and ${ }^{1} \mathrm{H}$ NMR was performed by the internal standard method.

Materials. 1H-Pyrrole-2-carboxylic acid, $1 H$-indole-2-carboxylic acid, $1 H$-indole-3-carboxylic acid, oxalyl chloride, 2 -iodoaniline, 2-chloroaniline, 2-bromoaniline, 2-bromo-4-(trifluoromethoxy)aniline, 2-bromo-4-methylaniline, 2-iodophenol, 1,1'-carbonyldiimidazole, benzoyl chloride, potassium tert-butoxide, and 1,4-dinitrobenzene were commercially available and used as received from the supplier. 2-Bromo-4-chloroaniline, 4-amino-3-bromobenzonitrile, 2-bromo-4methoxyaniline, and ethyl 4-amino-3-bromobenzoate were obtained by reported methods. ${ }^{48}$ THF was dried over $\mathrm{Na}$ metal and stored under nitrogen, over molecular sieves $(4 \AA)$. $\mathrm{CH}_{2} \mathrm{Cl}_{2}$ was distilled and stored over molecular sieves $(4 \AA)$. DMSO was stored over molecular sieves (4 ̊). Silica gel $(0.063-0.200 \mathrm{~mm})$ was used in column chromatography.

Representative Procedure for the Synthesis of Amide Derivatives $\mathbf{1 a}-\mathbf{i}, \mathbf{2} \mathbf{a}-\mathbf{f}$, and $\mathbf{3 a}-\mathbf{b}$. The procedure is representative of all these reactions, following previous reports. ${ }^{19 \mathrm{~d}, 34}$ They were carried out in a $25 \mathrm{~mL}$ three-neck round-bottomed flask equipped with nitrogen inlet and magnetic stirrer. $1 \mathrm{H}$-Pyrrole, $1 \mathrm{H}$-indole 2-carboxylic acid, or $1 \mathrm{H}$-indole 3 -carboxylic acid $(2 \mathrm{mmol})$ was heated at $50{ }^{\circ} \mathrm{C}$ in oxalyl chloride $(1 \mathrm{~mL})$ for $1 \mathrm{~h}$. The oxalyl chloride was then evaporated, and the resulting solid was dissolved in anhydrous dichloromethane $(3 \mathrm{~mL})$. The reaction was cooled in an ice bath, and 2haloaniline $(5 \mathrm{mmol})$ was added. After addition, the mixture was warmed to rt and stirred overnight. Water $(100 \mathrm{~mL})$ was then added, and the reaction mixture was extracted with dichloromethane $(3 \times 30 \mathrm{~mL})$. The organic layer was washed with a solution of $\mathrm{HCl} 10 \%(3 \times 30 \mathrm{~mL})$, dried over anhydrous sodium sulfate, filtered, and concentrated in vacuum. The product was purified by chromatography on silica gel.

The compounds $\mathbf{1 a}, \mathbf{1} \mathbf{b}, \mathbf{1 d}, \mathbf{1 f}, \mathbf{1} \mathbf{i}, \mathbf{2} \mathbf{a}, \mathbf{2} \mathbf{b}$, and $\mathbf{2 f}$ were previously reported and spectroscopy data are in agreement with the literature. ${ }^{19 \mathrm{~d}}$ Copies of ${ }^{1} \mathrm{H}$ and ${ }^{13} \mathrm{C}$ spectra are in the Supporting Information.

$\mathrm{N}$-(2-Chlorophenyl)-1H-pyrrole-2-carboxamide (1c). The amide was purified by column chromatography on silica gel eluting with a petroleum ether $/ \mathrm{CH}_{2} \mathrm{Cl}_{2}$ gradient $(100: 0 \rightarrow 30: 70)$ as white solid, mp 145.0-146.0 ${ }^{\circ} \mathrm{C} .{ }^{1} \mathrm{H}$ NMR $\left(400 \mathrm{MHz}, \mathrm{CDCl}_{3}\right) \delta_{\mathrm{H}}: 6.32$ $(1 \mathrm{H}, \mathrm{m}) ; 6.78-6.79(1 \mathrm{H}, \mathrm{m}) ; 7.02-7.03(1 \mathrm{H}, \mathrm{m}) ; 7.05-7.07(1 \mathrm{H}$, m); 7.28-7.32 (1H, m); $7.40(1 \mathrm{H}, \mathrm{dd}, J=8.1,1.5) ; 8.19(1 \mathrm{H}, \mathrm{s} \mathrm{br})$; $8.48(1 \mathrm{H}, \mathrm{dd}, J=8.3,1.5) ; 9.70(1 \mathrm{H}, \mathrm{s} \mathrm{br}) .{ }^{13} \mathrm{C}$ NMR $(101 \mathrm{MHz}$, $\left.\mathrm{CDCl}_{3}\right) \delta_{\mathrm{C}}: 110.0(\mathrm{CH}) ; 110.4(\mathrm{CH}) ; 121.2(\mathrm{CH}) ; 122.6(\mathrm{C}) ; 122.8$ $(\mathrm{CH}) ; 124.3(\mathrm{CH}) ; 125.9(\mathrm{C}) ; 127.8(\mathrm{CH}) ; 129.1(\mathrm{CH}) ; 134.7(\mathrm{C})$; $158.8(\mathrm{C}) .{ }^{1} \mathrm{H}-{ }^{1} \mathrm{H}$ COSY NMR $\left(\mathrm{CDCl}_{3}\right) \delta_{\mathrm{H}} / \delta_{\mathrm{H}}: 6.32 / 6.79 ; 6.32 /$ 7.02; 7.06/7.30; 7.06/7.40; 7.30/8.48. ${ }^{1} \mathrm{H}-{ }^{13} \mathrm{C}$ HSQC NMR $\left(\mathrm{CDCl}_{3}\right)$ $\delta_{\mathrm{H}} / \delta_{\mathrm{C}}: 6.32 / 110.4 ; 6.79 / 110.0 ; 7.02 / 122.8 ; 7.06 / 124.3 ; 7.30 / 127.8 ;$ 7.40/129.1; 8.48/121.2. ${ }^{1} \mathrm{H}-{ }^{13} \mathrm{C}$ HMBC NMR $\left(\mathrm{CDCl}_{3}\right) \delta_{\mathrm{H}} / \delta_{\mathrm{C}}: 6.32 /$ $122.9 ; 6.32 / 125.9 ; 6.79 / 122.9 ; 6.79 / 125.9 ; 7.02 / 110.4 ; 7.02 / 125.8$; $7.05 / 121.1 ; 7.05 / 122.5 ; 7.30 / 121.2 ; 7.30 / 122.6 ; 7.40 / 122.7 ; 7.40 /$ $129.1 ; 8.48 / 121.2 ; 8.48 / 122.8 ; 8.48 / 124.4 ; 8.48 / 134.8$. GC-MS $(\mathrm{m} / z): 220\left(24, \mathrm{M}^{+}\right) ; 185$ (54); 129 (30); 127 (100); 94 (59); 66 (30). HRMS (ESI) $\left[\mathrm{M}+\mathrm{H}^{+}\right]$calcd for $\mathrm{C}_{11} \mathrm{H}_{10} \mathrm{ClN}_{2} \mathrm{O}^{+}$221.0476, found 221.0477 .

$\mathrm{N}$-(2-Bromo-4-methoxyphenyl)-1 $\mathrm{H}$-pyrrole-2-carboxamide (1e). The amide was purified by column chromatography on silica gel eluting with a petroleum ether/diethyl ether gradient $(80: 20 \rightarrow 0: 100)$ and recrystallized in petroleum ether as white needle crystals, mp 200.0-201.0 ${ }^{\circ} \mathrm{C} .{ }^{1} \mathrm{H}$ NMR $\left(400 \mathrm{MHz}, \mathrm{CDCl}_{3}\right) \delta_{\mathrm{H}}: 3.80(3 \mathrm{H}, \mathrm{s}) ; 6.31$ $(1 \mathrm{H}, \mathrm{s}) ; 6.76(1 \mathrm{H}, \mathrm{s}) ; 6.91(1 \mathrm{H}, \mathrm{dd}, J=9.0,2.3) ; 7.00(1 \mathrm{H}, \mathrm{s} \mathrm{br}) ; 7.13$ $(1 \mathrm{H}, \mathrm{d}, J=2.3)$; $7.96(1 \mathrm{H}, \mathrm{s} \mathrm{br}) ; 8.27(1 \mathrm{H}, \mathrm{d}, J=9.0)$; $9.62(1 \mathrm{H}, \mathrm{s} \mathrm{br})$. ${ }^{13} \mathrm{C}$ NMR $\left(101 \mathrm{MHz}, \mathrm{CDCl}_{3}\right) \delta_{\mathrm{C}}: 55.7\left(\mathrm{OCH}_{3}\right) ; 109.7(\mathrm{CH}) ; 110.3$ $(\mathrm{CH}) ; 114.0(\mathrm{CH}) ; 114.3(\mathrm{C}) ; 117.6(\mathrm{CH}) ; 122.5(\mathrm{CH}) ; 122.8$ (CH); 125.9 (C); 129.1 (C); 156.3 (C); 158.7 (C). ${ }^{1} \mathrm{H}-{ }^{1} \mathrm{H}$ COSY 
$\operatorname{NMR}\left(\mathrm{CDCl}_{3}\right) \delta_{\mathrm{H}} / \delta_{\mathrm{H}}: 6.31 / 6.76 ; 6.91 / 7.13 ; 6.91 / 8.27 ; 7.00 / 6.31 ;$ $7.13 / 6.91 ; 8.27 / 6.91 .{ }^{1} \mathrm{H}-{ }^{13} \mathrm{C}$ HSQC NMR $\left(\mathrm{CDCl}_{3}\right) \delta_{\mathrm{H}} / \delta_{\mathrm{C}}: 3.80 /$ $55.7 ; 6.31 / 110.3 ; 6.76 / 109.7 ; 6.91 / 114.0 ; 7.00 / 122.5 ; 7.13 / 117.6$; 8.27/122.8. ${ }^{1} \mathrm{H}-{ }^{13} \mathrm{C} \mathrm{HMBC}$ NMR $\left(\mathrm{CDCl}_{3}\right) \delta_{\mathrm{H}} / \delta_{\mathrm{C}}: 3.80 / 156.3 ; 6.76 /$ 122.5 ; 6.91/117.6; 6.91/129.1; 7.00/109.7; 7.00/110.3; 7.00/125.9; $7.13 / 114.0 ; 7.13 / 129.1 ; 7.13 / 156.3 ; 8.27 / 114.3 ; 8.27 / 129.1 ; 8.27 /$ 156.3. GC-MS $(\mathrm{m} / \mathrm{z}): 296\left(14, \mathrm{M}^{+}+1\right) ; 294$ (15); 215 (12); 204 (9); 203 (100); 202 (14); 201 (99); 200 (8); 188 (36); 186 (47); 106 (14); 95 (8); 94 (83); 93 (6); 80 (9); 79 (17); 78 (13); 66 (71); 65 (13); 63 (10); 52 (14); 51 (11). HRMS (ESI) $\left[\mathrm{M}+\mathrm{H}^{+}\right]$calcd for $\mathrm{C}_{12} \mathrm{H}_{12} \mathrm{BrN}_{2} \mathrm{O}_{2}{ }^{+} 295.0077$, found 295.0081 .

$\mathrm{N}$-(2-Bromo-4-(trifluoromethoxy)phenyl)-1 H-pyrrole-2-carboxamide (1g). The product was isolated as white solid, $\mathrm{mp} 154.8-$ $156.6{ }^{\circ} \mathrm{C} .{ }^{1} \mathrm{H}\left(400 \mathrm{MHz}, \mathrm{CDCl}_{3}\right) \delta_{\mathrm{H}}: 6.34(1 \mathrm{H}, \mathrm{m}), 6.80(1 \mathrm{H}, \mathrm{m})$, $7.04(1 \mathrm{H}, \mathrm{m}), 7.20-7.49(1 \mathrm{H}, \mathrm{m}), 7.50-7.74(1 \mathrm{H}, \mathrm{ddd}, J=70.7$, 5.7, 3.3); $8.15(1 \mathrm{H}, \mathrm{s} \mathrm{br}) ; 8.52(1 \mathrm{H}, \mathrm{d}, J=9.11), 9.34(1 \mathrm{H}, \mathrm{s} \mathrm{br}) .{ }^{19} \mathrm{~F}$ $\left(377 \mathrm{MHz}, \mathrm{CDCl}_{3}\right) \delta_{\mathrm{F}}:-58.24 .{ }^{13} \mathrm{C} \mathrm{NMR}\left(101 \mathrm{MHz}, \mathrm{CDCl}_{3}\right) \delta_{\mathrm{C}}$ : $110.4(\mathrm{CH}) ; 110.6(\mathrm{CH}) ; 112.9(\mathrm{C}) ; 121.3(\mathrm{CH}) ; 121.7(\mathrm{CH}) ; 123.2$ $(\mathrm{CH}) ; 125.1(\mathrm{CH}) ; 125.5(\mathrm{C}) ; 134.8(\mathrm{C}) ; 144.5(\mathrm{C}) ; 158.7$ (C). ${ }^{1} \mathrm{H}-{ }^{1} \mathrm{H}$ COSY NMR $\left(\mathrm{CDCl}_{3}\right) \delta_{\mathrm{H}} / \delta_{\mathrm{H}}: 6.34 / 6.81 ; 6.34 / 7.04 ; 6.80 /$ 7.04; 7.35/8.52. GC-MS (m/z): $348\left(3, \mathrm{M}^{+}-1\right) ; 269$ (14); 257 (25); 255 (22); 94 (100); 69 (19); 66 (46). HRMS (ESI) $\left[\mathrm{M}+\mathrm{H}^{+}\right]$ calcd $\mathrm{C}_{12} \mathrm{H}_{9} \mathrm{BrF}_{3} \mathrm{~N}_{2} \mathrm{O}_{2}^{+}$348.9794, found 348.9820 .

Ethyl 3-Bromo-4-(1 H-pyrrole-2-carboxamido)benzoate (1h). The amide was purified by radial thin-layer chromatography on silica gel eluting with a petroleum ether/diethyl ether gradient (50:50) and recrystallized in acetone as white needle crystals, $\mathrm{mp} 202.8-203.6{ }^{\circ} \mathrm{C}$. ${ }^{1} \mathrm{H}$ NMR (400 MHz, DMSO- $\left.d_{6}\right) \delta_{\mathrm{H}}: 1.32(3 \mathrm{H}, \mathrm{t}, J=7.1) ; 4.32(2 \mathrm{H}, \mathrm{q}$, $J=7.1)$; 6.19-6.21 (1H, m); 7.02-7.03 (1H, m); 7.06-7.07 (1H, m); $7.91(1 \mathrm{H}, \mathrm{d}, J=8.5) ; 7.97(1 \mathrm{H}, \mathrm{dd}, J=8.5,1.8) ; 8.17(1 \mathrm{H}, \mathrm{d}, J=1.8)$, $9.43(1 \mathrm{H}, \mathrm{s}$ br $), 11.82(1 \mathrm{H}, \mathrm{s}$ br$) .{ }^{13} \mathrm{C}$ NMR $\left(101 \mathrm{MHz}, \mathrm{DMSO}-d_{6}\right) \delta_{\mathrm{C}}$ : $14.6\left(\mathrm{CH}_{3}\right) ; 61.6\left(\mathrm{CH}_{2}\right) ; 109.7(\mathrm{CH}) ; 112.7(\mathrm{CH}) ; 118.0(\mathrm{C}) ; 123.9$ $(\mathrm{CH}) ; 125.6(\mathrm{C}) ; 126.5(\mathrm{CH}) ; 128.0(\mathrm{C}) ; 129.4(\mathrm{CH}) ; 133.7(\mathrm{CH})$; 141.2 (C); 159.2 (C); 164.7 (C). ${ }^{1} \mathrm{H}-{ }^{1} \mathrm{H}$ COSY NMR (DMSO-d $d_{6}$ ) $\delta_{\mathrm{H}} / \delta_{\mathrm{H}}: 1.32 / 4.32 ; 6.20 / 7.07 ; 7.03 / 11.82 ; 8.17 / 7.97 .{ }^{1} \mathrm{H}-{ }^{13} \mathrm{C}$ HSQC NMR (DMSO- $\left.d_{6}\right) \delta_{\mathrm{H}} / \delta_{\mathrm{C}}: 1.32 / 14.6 ; 4.32 / 61.6 ; 6.20 / 109.7 ; 7.02 /$ $123.9 ; \quad 7.07 / 112.7 ; \quad 7.91 / 126.5 ; \quad 7.97 / 129.4 ; \quad 8.17 / 133.7 .{ }^{1} \mathrm{H}-{ }^{13} \mathrm{C}$ HMBC NMR (DMSO- $\left.d_{6}\right) \delta_{\mathrm{H}} / \delta_{\mathrm{C}}: 1.32 / 61.6 ; 4.32 / 14.6 ; 4.32 / 164.7$; $7.02 / 109.7 ; 7.02 / 125.6 ; 7.91 / 118.0 ; 7.91 / 128.0 ; 7.97 / 133.7 ; 7.97 /$ $141.2 ; 7.97 / 164.7 ; 8.17 / 118.0 ; 8.17 / 129.4 ; 8.17 / 141.2 ; 8.17 / 164.7$; 9.43/118.0; 9.43/126.5; 8.17/159.2. GC-MS $(m / z): 338\left(15, \mathrm{M}^{+}+1\right)$; 336 (16, $\left.\mathrm{M}^{+}-1\right) ; 258$ (17); 257 (72); 245 (48); 244 (7); 243 (52); 217 (19); 215 (20); 200 (28); 199 (7); 198 (32); 94 (100); 90 (11); 66 (40). HRMS (ESI) $\left[\mathrm{M}+\mathrm{Na}^{+}\right]$calcd for $\mathrm{C}_{14} \mathrm{H}_{13} \mathrm{BrN}_{2} \mathrm{O}_{3} \mathrm{Na}^{+} 359.0002$, found 359.0023 .

$\mathrm{N}$-(2-Bromo-4-methoxyphenyl)- $1 \mathrm{H}$-indole-2-carboxamide (2c). The amide was purified by radial thin-layer chromatography eluting with a petroleum ether/diethyl ether gradient $(90: 10 \rightarrow$ 80:20) and recrystallized in $\mathrm{CH}_{2} \mathrm{Cl}_{2}$ as white needle crystals, mp 182.7$183.4{ }^{\circ} \mathrm{C} .{ }^{1} \mathrm{H}$ NMR $\left(400 \mathrm{MHz}, \mathrm{CDCl}_{3}\right) \delta_{\mathrm{H}}: 3.81(3 \mathrm{H}, \mathrm{s}) ; 6.94(1 \mathrm{H}$, $\mathrm{dd}, J=9.1,2.8) ; 7.06(1 \mathrm{H}, \mathrm{d}, J=1.2) ; 7.17-7.19(2 \mathrm{H}, \mathrm{m}) ; 7.29-7.33$ $(1 \mathrm{H}, \mathrm{m}) ; 7.46(1 \mathrm{H}, \mathrm{d}, J=8.3) ; 7.70(1 \mathrm{H}, \mathrm{d}, J=8.0) ; 8.30(1 \mathrm{H}, \mathrm{s}) ; 8.37$ $(1 \mathrm{H}, \mathrm{d}, J=9.1) ; 9.73(1 \mathrm{H}, \mathrm{s}) .{ }^{13} \mathrm{C}$ NMR $\left(101 \mathrm{MHz}, \mathrm{CDCl}_{3}\right) \delta_{\mathrm{C}}: 55.7$ $\left(\mathrm{OCH}_{3}\right) ; 102.8(\mathrm{CH}) ; 112.1(\mathrm{CH}) ; 114.0(\mathrm{CH}) ; 114.5(\mathrm{C}) ; 117.6$ $(\mathrm{CH}) ; 120.9(\mathrm{CH}) ; 122.1(\mathrm{CH}) ; 123.0(\mathrm{CH}) ; 125.0(\mathrm{CH}) ; 127.6$ (C); 128.8 (C); 130.6 (C); 136.8 (C); 156.6 (C); 159.4 (C). ${ }^{1} \mathrm{H}-{ }^{1} \mathrm{H}$ COSY NMR $\left(\mathrm{CDCl}_{3}\right) \delta_{\mathrm{H}} / \delta_{\mathrm{H}}: 6.94 / 7.16 ; 6.94 / 8.34 ; 7.06 / 9.73 ; 7.17 /$ $7.30 ; 7.17 / 7.70 ; 7.31 / 7.46 .{ }^{1} \mathrm{H}-{ }^{13} \mathrm{C}$ HSQC NMR $\left(\mathrm{CDCl}_{3}\right) \delta_{\mathrm{H}} / \delta_{\mathrm{C}}$ : $3.81 / 55.7 ; 6.93 / 114.0 ; 7.06 / 102.8 ; 7.17 / 117.6 ; 7.16 / 120.9 ; 7.31 /$ 125,$0 ; 7.45 / 112.1 ; 7.69 / 122.1 ; 8.36 / 123.0{ }^{1} \mathrm{H}-{ }^{13} \mathrm{C}$ HMBC NMR $\left(\mathrm{CDCl}_{3}\right) \delta_{\mathrm{H}} / \delta_{\mathrm{C}}: 3.81 / 156.6 ; 6.94 / 117.6 ; 6.94 / 128.8 ; 6.94 / 156.6$; $7.06 / 127.6 ; 7.06 / 130.56 ; 7.06 / 136.8 ; 7.17 / 112.1 ; 7.17 / 114.0 ; 7.17 /$ $127.6 ; 7.31 / 122.1 ; 7.31 / 136.8 ; 7.45 / 120.9 ; 7.46 / 127.6 ; 7.70 / 102.8$; $7.70 / 112.1 ; 7.70 / 125.0 ; 7.70 / 136.8 ; 8.30 / 114.5 ; 8.30 / 123.0 ; 8.30 /$ 159.4; 8.37/114.5; 8.37/128.7; 8.37/156.6; 9.74/127.6. GC-MS $(\mathrm{m} / \mathrm{z})$ : 347 (5); 346 (37); 344 (35); 266 (17); 265 (98); 203 (100); 201 (93); 188 (18); 186 (23); 144 (66); 116 (29); 115 (12); 89 (61); 63 (10). HRMS (ESI) $\left[\mathrm{M}+\mathrm{H}^{+}\right]$calcd for $\mathrm{C}_{16} \mathrm{H}_{14} \mathrm{BrN}_{2} \mathrm{O}_{2}{ }^{+} 345.0233$, found 345.0247.
$\mathrm{N}$-(2-Bromo-4-(trifluoromethoxy)phenyl)-1H-indole-2-carboxamide (2d). The amide was purified by column chromatography on silica gel eluting with petroleum ether/ $\mathrm{CH}_{2} \mathrm{Cl}_{2}$ gradient $(90: 10 \rightarrow$ 20:80) as needle-like white crystals, mp $219.0-220.0{ }^{\circ} \mathrm{C} .{ }^{1} \mathrm{H}$ NMR $\left(400 \mathrm{MHz}, \mathrm{CDCl}_{3}\right) \delta_{\mathrm{H}}: 7.10(1 \mathrm{H}, \mathrm{d}, J=1.6) ; 7.17-7.21(1 \mathrm{H}, \mathrm{m})$, $7.27-7.29(1 \mathrm{H}, \mathrm{m}) ; 7.32-7.36(1 \mathrm{H}, \mathrm{m}) ; 7.46(1 \mathrm{H}, \mathrm{d}, J=8.4) ; 7.51$ $(1 \mathrm{H}, \mathrm{d}, J=2.0) ; 7.72(1 \mathrm{H}, \mathrm{d}, J=8.0) ; 8.47(1 \mathrm{H}, \mathrm{s} \mathrm{br}) ; 8.59(1 \mathrm{H}, \mathrm{d}, J=$ 8.8); $9.44(1 \mathrm{H}, \mathrm{s} \mathrm{br}) .{ }^{13} \mathrm{C}$ NMR $\left(101 \mathrm{MHz}, \mathrm{CDCl}_{3}\right) \delta_{\mathrm{C}}: 103.5(\mathrm{CH})$; $112.1(\mathrm{CH}) ; 113.2(\mathrm{C}) ; 120.4\left(\mathrm{CF}_{3}, \mathrm{q}, J=256\right) ; 121.2(\mathrm{CH}) ; 121.4$ $(\mathrm{CH}) ; 121.9(\mathrm{CH}) ; 122.3(\mathrm{CH}) ; 125.2(\mathrm{CH}) ; 125.5(\mathrm{CH}) ; 127.6(\mathrm{C})$ ; 130.0 (C); 134.5 (C); 136.9 (C); 144.9 (C); 159.4 (C). ${ }^{19}$ F NMR $\left(377 \mathrm{M}, \mathrm{CDCl}_{3}\right) \delta_{\mathrm{F}}:-58.20 .{ }^{1} \mathrm{H}-{ }^{1} \mathrm{H}$ COSY NMR $\left(\mathrm{CDCl}_{3}\right) \delta_{\mathrm{H}} / \delta_{\mathrm{H}}$ : $7.10 / 9.44 ; 7.19 / 7.34 ; 7.19 / 7.72 ; 7.28 / 7.51 ; 7.28 / 8.59 ; 7.34 / 7.46$. ${ }^{1} \mathrm{H}-{ }^{13} \mathrm{C}$ HSQC NMR $\left(\mathrm{CDCl}_{3}\right) \delta_{\mathrm{H}} / \delta_{\mathrm{C}}: 7.10 / 103.5 ; 7.19 / 121.2 ; 7.28 /$ $121.4 ; 7.34 / 125.5 ; 7.46 / 112.1 ; 7.51 / 125.2 ; 7.72 / 122.3 ; 8.59 / 121.9$. GC/MS (m/z): $399\left(2, \mathrm{M}^{+}\right) ; 319$ (21); 145 (10); $144(100) ; 143$ (24); 116 (28); 115 (17); 89 (66); 69 (17); 63 (12). HRMS (ESI) $\left[\mathrm{M}+\mathrm{H}^{+}\right]$calcd for $\mathrm{C}_{16} \mathrm{H}_{10} \mathrm{BrF}_{3} \mathrm{~N}_{2} \mathrm{O}_{2}{ }^{+} 398.9951$, found 398.9968 .

Ethyl 3-Bromo-4-(1 $\mathrm{H}$-indole-2-carboxamido)benzoate (2e). The amide was purified by column chromatography on silica gel eluting with petroleum ether/diethyl ether gradient $(100: 0 \rightarrow 50: 50)$ as a yellow solid, mp $235.0-236.0{ }^{\circ} \mathrm{C}$. ${ }^{1} \mathrm{H}$ NMR (400 MHz, DMSO$\left.d_{6}\right) \delta_{\mathrm{H}}: 1.35(3 \mathrm{H}, \mathrm{t}, J=7.2) ; 4.35(2 \mathrm{H}, \mathrm{q}, J=7.2) ; 7.07-7.11(1 \mathrm{H}, \mathrm{m})$, $7.23-7.27(1 \mathrm{H}, \mathrm{m}) ; 7.43-7.49(1 \mathrm{H}, \mathrm{m}) ; 7.48(1 \mathrm{H}, \mathrm{d}, J=8.1) ; 7.70$ $(1 \mathrm{H}, \mathrm{d}, J=8.1) ; 7.90(1 \mathrm{H}, \mathrm{d}, J=8.4) ; 8.02(1 \mathrm{H}, \mathrm{dd}, J=8.4,1.9) ; 8.22$ $(1 \mathrm{H}, \mathrm{d}, J=1.9) ; 10.04(1 \mathrm{H}, \mathrm{s} \mathrm{br}) ; 11.86(1 \mathrm{H}, \mathrm{s} \mathrm{br}) .{ }^{13} \mathrm{C}$ NMR $(101$ MHz, DMSO-d $\left.d_{6}\right) \delta_{\mathrm{C}}: 14.6\left(\mathrm{CH}_{3}\right) ; 61.7\left(\mathrm{CH}_{2}\right) ; 105.1(\mathrm{CH}) ; 112.9$ $(\mathrm{CH}) ; 119.1(\mathrm{C}) ; 120.6(\mathrm{CH}) ; 122.4(\mathrm{CH}) ; 124.6(\mathrm{CH}) ; 127.4(\mathrm{CH})$; $127.6(\mathrm{C}) ; 128.8(\mathrm{CH}) ; 129.4(\mathrm{C}) ; 131.0(\mathrm{C}) ; 133.8(\mathrm{CH}) ; 137.5$ (C); 140.9 (C); 160.1 (C); 164.7 (C). ${ }^{1} \mathrm{H}-{ }^{1} \mathrm{H}$ COSY NMR (DMSOd $) \delta_{\mathrm{H}} / \delta_{\mathrm{H}}: 1.35 / 4.35 ; 7.09 / 7.25 ; 7.09 / 7.70 ; 7.25 / 7.48 ; 7.43 / 11.86$; 7.90/8.02. ${ }^{1} \mathrm{H}^{13}{ }^{13} \mathrm{C}$ HSQC NMR (DMSO- $d_{6}$ ) $\delta_{\mathrm{H}} / \delta_{\mathrm{C}}: 1.35 / 14.6 ; 4.35 /$ 61.7; 7.09/120.6; 7.25/124.6; 7.43/105.1; 7.48/112.9; 7.70/122.4; 7.90/127.4; 8.02/128.8; 8.22/133.8. ${ }^{1} \mathrm{H}-{ }^{13} \mathrm{C}$ HMBC NMR (DMSO$\left.d_{6}\right) \delta_{\mathrm{H}} / \delta_{\mathrm{C}}: 1.35 / 61.7 ; 4.35 / 14.6 ; 4.35 / 164.7 ; 7.09 / 112.9 ; 7.09 / 127.4$; $7.25 / 122.4 ; 7.25 / 137.5 ; 7.43 / 127.6 ; 7.43 / 127.4 ; 7.43 / 137.5 ; 7.48 /$ 120.6 ; 7.48/127.6; 7.70/124.6; 7.90/119.1; 7.90/128.8; 8.02/133.8; $8.02 / 140.9 ; 8.02 / 164.7 ; 8.22 / 119.1 ; 8.22 / 129.6 ; 8.22 / 140.9 ; 10.04 /$ $160.1 ; 11.86 / 127.6$. HRMS (ESI) $\left[\mathrm{M}+\mathrm{Na}^{+}\right]$calcd for $\mathrm{C}_{18} \mathrm{H}_{15} \mathrm{Br}-$ $\mathrm{N}_{2} \mathrm{O}_{3} \mathrm{Na}^{+}$409.0158, found 409.0158 .

$N$-(2-Bromophenyl)-1H-indole-3-carboxamide (3a). The amide was purified by column chromatography on silica gel eluting with petroleum ether/diethyl ether gradient $(100: 0 \rightarrow 70: 30)$ as a palid orange solid, mp $204.0-205.0{ }^{\circ} \mathrm{C}$ (lit. $\left.197{ }^{\circ} \mathrm{C}\right) .{ }^{49} \mathrm{H}$ NMR $(400$ $\left.\mathrm{MHz}, \mathrm{CDCl}_{3}\right) \delta_{\mathrm{H}}: 7.14-7.23(3 \mathrm{H}, \mathrm{m}) ; 7.40-7.44(1 \mathrm{H}, \mathrm{m}) ; 7.44-7.51$ $(1 \mathrm{H}, \mathrm{m}) ; 7.71(1 \mathrm{H}, \mathrm{dd}, J=8.0,1.3) ; 7.74(1 \mathrm{H}, \mathrm{dd}, J=8.0,1.5)$; $8.16-$ $8.18(1 \mathrm{H}, \mathrm{m}) ; 8.31(1 \mathrm{H}, \mathrm{d}, J=2.8) ; 9.34(1 \mathrm{H}, \mathrm{s} \mathrm{br}) ; 11.79(1 \mathrm{H}, \mathrm{s} \mathrm{br})$. ${ }^{13} \mathrm{C}$ NMR $\left(101 \mathrm{MHz}, \mathrm{CDCl}_{3}\right) \delta_{\mathrm{C}}: 110.5(\mathrm{C}) ; 112.6(\mathrm{CH}) ; 119.6(\mathrm{C})$; $121.3(\mathrm{CH}) ; 121.3(\mathrm{CH}) ; 122.7(\mathrm{CH}) ; 126.6(\mathrm{C}) ; 127.2(\mathrm{CH}) ; 128.3$ $(\mathrm{CH}) ; 128.4(\mathrm{CH}) ; 129.6(\mathrm{CH}) ; 133.0(\mathrm{CH}) ; 136.8(\mathrm{C}) ; 137.3(\mathrm{C})$; $163.5(\mathrm{C}) .{ }^{1} \mathrm{H}-{ }^{1} \mathrm{H}$ COSY NMR $\left(\mathrm{CDCl}_{3}\right) \delta_{\mathrm{H}} / \delta_{\mathrm{H}}: 7.18 / 7.42 ; 7.18 /$ 7.50; 7.18/7.71; 7.18/8.17; 7.42/7.74; 8.31/11.79. ${ }^{1} \mathrm{H}-{ }^{13} \mathrm{C}$ HSQC NMR $\left(\mathrm{CDCl}_{3}\right) \quad \delta_{\mathrm{H}} / \delta_{\mathrm{C}}: 7.18 / 121.3 ; 7.18 / 122.7 ; 7.18 / 127.2 ; 7.42 /$ 128.4; 7.50/112.6; 7.71/133.0; 7.74/128.3, 8.17/121.3, 8.31/129.6. ${ }^{1} \mathrm{H}-{ }^{13} \mathrm{C}$ HMBC NMR $\left(\mathrm{CDCl}_{3}\right) \delta_{\mathrm{H}} / \delta_{\mathrm{C}}: 7.18 / 112.6 ; 7.18 / 119.6 ; 7.18 /$ $121.3 ; 7.18 / 126.6 ; 7.18 / 127.2 ; 7.18 / 128.3 ; 7.18 / 136.8 ; 7.42 / 119.6$; $7.42 / 133.0 ; 7.42 / 137.3 ; 7.50 / 121.3 ; 7.50 / 126.6 ; 7.50 / 133.0 ; 7.71 /$ $119.6 ; 7.71 / 128.4 ; 7.71 / 137.3 ; 7.73 / 119.6 ; 7.73 / 127.2 ; 8.17 / 110.5$; $8.17 / 122.7 ; 8.17 / 136.8 ; 8.31 / 110.5 ; 8.31 / 126.6 ; 8.31 / 136.8 ; 8.30 /$ $129.6 ; 9.34 / 119.6 ; 9.34 / 128.4 ; 9.34 / 163.5 ; 11.79 / 110.5 ; 11.79 / 126.6$. GC/MS (m/z): 316 (10), 314 (2), 313 (10), 235 (32), 173 (24), 171 (19), 145 (15), 144 (100), 118 (14), 116 (26), 89 (25).

$\mathrm{N}$-(2-Bromo-4-methylphenyl)- $1 \mathrm{H}$-indole-3-carboxamide (3b). The amide was obtained by the reported methodology and was purified by radial thin-layer chromatography eluting with petroleum ether/diethyl ether (50:50) and was isolated as white solid, mp 208.5$210.1{ }^{\circ} \mathrm{C} .{ }^{1} \mathrm{H}$ NMR $\left(400 \mathrm{MHz}\right.$, acetone- $\left.d_{6}\right) \delta_{\mathrm{H}}: 2.32(3 \mathrm{H}, \mathrm{s}) ; 7.20-$ $7.26(3 \mathrm{H}, \mathrm{m}) ; 7.48(1 \mathrm{H}, \mathrm{m}) ; 7.52-7.55(1 \mathrm{H}, \mathrm{m}) ; 8.21(2 \mathrm{H}, \mathrm{dd}, J=$ 5.6, 2.6); 8.30 (1H, dd, $J=5.2,4.0) ; 8.47(1 \mathrm{H}, \mathrm{s} \mathrm{br}) ; 10.95$ (1H, s br). ${ }^{13} \mathrm{C}$ NMR $\left(101 \mathrm{MHz}\right.$, acetone- $\left.d_{6}\right) \delta_{\mathrm{C}}: 20.5\left(\mathrm{CH}_{3}\right) ; 112.4(\mathrm{C}) ; 113.0$ 
$(\mathrm{CH}) ; 115.6(\mathrm{C}) ; 121.6(\mathrm{CH}) ; 122.1(\mathrm{CH}) ; 123.5(\mathrm{CH}) ; 124.5$ $(\mathrm{CH}) ; 126.8(\mathrm{C}) ; 129.4(\mathrm{CH}) ; 129.6(\mathrm{CH}) ; 133.4(\mathrm{CH}) ; 135.3(\mathrm{C})$; 136.0 (C); 137.8 (C); $163.6(\mathrm{C}) .{ }^{1} \mathrm{H}-{ }^{1} \mathrm{H}$ COSY NMR (acetone- $d_{6}$ ) $\delta_{\mathrm{H}} / \delta_{\mathrm{H}}: 7.23 / 7.55 ; 7.23 / 8.21 ; 7.23 / 8.30 ; 7.54 / 8.30 ; 8.21 / 10.95$. ${ }^{1} \mathrm{H}-{ }^{13} \mathrm{C}$ HSQC NMR (acetone- $\left.d_{6}\right) \quad \delta_{\mathrm{H}} / \delta_{\mathrm{C}}: 2.32 / 20.5 ; 7.23 / 122.1$; $7.23 / 123.5 ; 7.23 / 129.6 ; 7.48 / 133.4 ; 7.54 / 113.0 ; 8.21 / 129.4 ; 8.22 /$ 124.5; 8.31/121.6. ${ }^{1} \mathrm{H}-{ }^{13} \mathrm{C}$ HMBC NMR (acetone- $d_{6}$ ) $\delta_{\mathrm{H}} / \delta_{\mathrm{C}}: 2.32 /$ $129.6 ; 2.32 / 133.4 ; 2.32 / 136.0 ; 7.23 / 113.0 ; 7.23 / 121.6 ; 7.23 / 133.4$; $7.23 / 135.3 ; 7.48 / 115.6 ; 7.48 / 129.6 ; 7.48 / 135.3 ; 7.54 / 122.1 ; 8.21 /$ $112.4 ; 8.21 / 115.6 ; 8.21 / 126.8 ; 8.21 / 135.9 ; 8.21 / 137.8 ; 8.30 / 123.5$. GC-MS (m/z): $331(2) ; 330(13) ; 328\left(11, \mathrm{M}^{+}\right) ; 249$ (26); 187 (61); 186 (8); 185 (65); 144 (100); 116 (36); 106 (15); 89 (27). HRMS (ESI) $\left[\mathrm{M}+\mathrm{H}^{+}\right]$calcd for $\mathrm{C}_{16} \mathrm{H}_{13} \mathrm{BrN}_{2} \mathrm{O}^{+} 329.0284$, found 329.0303.

Procedure for the Synthesis of $\mathrm{N}$-(2-Bromophenyl)benzamide (8). To a Schlenk tube was added $10 \mathrm{~mL}$ of $\mathrm{CH}_{2} \mathrm{Cl}_{2}, 2$ mmol of 2-bromoaniline $(344 \mathrm{mg}, 0.226 \mathrm{~mL})$, and $2.5 \mathrm{mmol}$ of triethylamine $(253 \mathrm{mg}, 0.348 \mathrm{~mL})$. The reaction was cooled in an ice bath, and $2.5 \mathrm{mmol}$ of benzoyl chloride $(0.290 \mathrm{~mL})$ was added. After addition, the mixture was warmed to rt and stirred overnight. Water $(100 \mathrm{~mL})$ was added, and the reaction mixture was extracted with dichloromethane $(3 \times 30 \mathrm{~mL})$. The organic layer was washed with a solution of $\mathrm{HCl} 10 \%(3 \times 30 \mathrm{~mL})$, dried with anhydrous sodium sulfate, filtered, and concentrated in vacuum. The product 8 was obtained in $90 \%$ (497 $\mathrm{mg}$ ) isolated yield as yellowish solid, $\mathrm{mp} 105.0-$ 106.0 ${ }^{\circ} \mathrm{C}$ (lit. 107.0-108.0 $\left.{ }^{\circ} \mathrm{C}\right) .{ }^{49}{ }^{1} \mathrm{H} \mathrm{NMR}\left(400 \mathrm{MHz}, \mathrm{CDCl}_{3}\right) \delta_{\mathrm{H}}$ : 7.00-7.04 (1H, m); 7.36-7.40 (1H, m); 7.51-7.61 (4H, m); 7.95 $(2 \mathrm{H}, \mathrm{d}, J=7.2)$; 8.47 (1H, s br); $8.56(1 \mathrm{H}, \mathrm{dd}, J=8.3,1.1) .{ }^{13} \mathrm{C} \mathrm{NMR}$ $\left(101 \mathrm{MHz}, \mathrm{CDCl}_{3}\right) \delta_{\mathrm{C}}: 113.8(\mathrm{C}) ; 121.8(\mathrm{CH}), 125.3(\mathrm{CH}) ; 127.1$ $(\mathrm{CH}) ; 128.6(\mathrm{CH}) ; 129.0(\mathrm{CH}) ; 132.2(\mathrm{CH}) ; 132.3(\mathrm{CH}) ; 134.6$ (C); 135.8 (C); 165.3 (C).

Procedure for the Synthesis of 2-lodophenyl-1H-indole-2carboxylate (17). The amide was obtained by the reported methodology. The spectroscopy data of product $\mathbf{1 7}$ is in agreement with the literature. ${ }^{19 \mathrm{~d}}$ Copies of ${ }^{1} \mathrm{H}$ and ${ }^{13} \mathrm{C}$ spectra are in the Supporting Information.

Representative Procedure for Photostimulated Reactions. Preparation of Benzoxazole Derivatives in Liquid Ammonia. The following procedure is representative for all these reactions. Liquid ammonia $(200 \mathrm{~mL})$, previously dried over $\mathrm{Na}$ metal, was distilled into a $250 \mathrm{~mL}$ three-necked, round-bottomed flask equipped with a coldfinger condenser, a nitrogen inlet, and a magnetic stirrer. The base $(t-\mathrm{BuOK})$ and then the substrate were added to the liquid ammonia, and the solution was irradiated for the time specified for each substrate. The reaction was quenched with an excess of ammonium nitrate, and the liquid ammonia was allowed to evaporate. Water was added to the residue, and the mixture was extracted with $\mathrm{CH}_{2} \mathrm{Cl}_{2}(3 \times 30 \mathrm{~mL})$. The organic layer was washed with water, dried over anhydrous sodium sulfate, filtered, and the solvent was removed to leave the crude products. The products were separated and isolated by chromatography on silica gel. The yield of halide ions in the aqueous solution were determined potentiometrically.

Preparation of Benzoxazole Derivatives in DMSO. The following procedure is representative for all these reactions. The reaction was carried out in a flame-dried Schlenk tube equipped with a nitrogen inlet and magnetic stirrer. Dried DMSO $(4 \mathrm{~mL})$ was deoxygenated, the $t$-BuOK and the substrate were added, and the reaction mixture was irradiated for the time specified for each substrate. The reaction was quenched with water and ammonium nitrate in excess. The residue was extracted with $\mathrm{CH}_{2} \mathrm{Cl}_{2}(3 \times 30 \mathrm{~mL})$. The organic layer was washed with water, dried over anhydrous sodium sulfate, filtered, and the solvent was removed to leave the crude products. The products were separated and isolated by chromatography on silica gel. The halide ions in the aqueous solution were determined potentiometrically.

Preparation of Chromeno[3,4-b]indol-6(7H)-one Derivatives in Liquid Ammonia. This product was obtained following the same procedure for benzoxazole derivatives.
Preparation of Chromeno[3,4-b]indol-6(7H)-one Derivatives in DMSO. This product was obtained following the same procedure for benzoxazole derivatives.

2-(1H-Pyrrol-2-yl)benzo[d]oxazole (4a). The benzoxazole was purified by radial thin-layer chromatography eluting with petroleum ether/diethyl ether $(90: 10 \rightarrow 50: 50)$ and was isolated as a white solid, mp $159.0-161.0{ }^{\circ} \mathrm{C}\left(\right.$ lit. $\left.149{ }^{\circ} \mathrm{C}\right) .{ }^{50}{ }^{1} \mathrm{H}$ NMR $\left(400 \mathrm{MHz}, \mathrm{CDCl}_{3}\right) \delta_{\mathrm{H}}$ : 6.38-6.39 (1H, m); 7.04-7.05 (1H, m); $7.10(1 \mathrm{H}, \mathrm{m}) ; 7.28-7.35$ $(2 \mathrm{H}, \mathrm{m})$; 7.53-7.55 (1H, m); 7.65-7.68 (1H, m); $10.51(1 \mathrm{H}, \mathrm{s} \mathrm{br})$. ${ }^{13} \mathrm{C}$ NMR $\left(101 \mathrm{MHz}, \mathrm{CDCl}_{3}\right) \delta_{\mathrm{C}}: 110.4(\mathrm{CH}) ; 110.8(\mathrm{CH}) ; 113.2$ $(\mathrm{CH}) ; 118.8(\mathrm{CH}) ; 119.8(\mathrm{C}) ; 123.0(\mathrm{CH}) ; 124.4(\mathrm{CH}) ; 124.6$ $(\mathrm{CH}) ; 141.8$ (C); 150.2 (C); 158.2 (C). ${ }^{1} \mathrm{H}-{ }^{1} \mathrm{H}$ COSY NMR $\left(\mathrm{CDCl}_{3}\right) \delta_{\mathrm{H}} / \delta_{\mathrm{H}}: 6.38 / 7.05 ; 6.38 / 7.10 ; 7.32 / 7.54 ; 7.32 / 7.66 .{ }^{1} \mathrm{H}-{ }^{13} \mathrm{C}$ HSQC NMR $\left(\mathrm{CDCl}_{3}\right) \delta_{\mathrm{H} /} \delta_{\mathrm{C}}: 6.38 / 110.8 ; 7.05 / 123.0 ; 7.10 / 113.2$; 7.32/124.4; 7.32/124.6; 7.54/110.4; 7.66/118.8. ${ }^{1} \mathrm{H}-{ }^{13} \mathrm{C}$ HMBC NMR $\left(\mathrm{CDCl}_{3}\right) \delta_{\mathrm{H}} \delta_{\mathrm{C}}: 6.38 / 113.2 ; 6.38 / 119.8 ; 6.38 / 123.0 ; 7.05 /$ 110.8 ; 7.05/113.2; 7.10/119.8; 7.10/123.0; 7.32/118.8; 7.32/141.8; $7.32 / 150.4 ; 7.54 / 124.4 ; 7.54 / 124.6 ; 7.54 / 141.8 ; 7.54 / 150.2 ; 7.66 /$ $124.4 ; 7.66 / 124.5 ; 7.66 / 141.9 ; 7.66 / 150.2 .{ }^{1} \mathrm{H}-{ }^{1} \mathrm{H}$ NOESY NMR $\left(\mathrm{CDCl}_{3}\right) \delta_{\mathrm{H}} \delta_{\mathrm{H}}: 6.38 / 7.09 ; 7.05 / 6.38 ; 7.05 / 10.51$. GC-MS $(\mathrm{m} / z)$ : 185 (13); $184\left(100, \mathrm{M}^{+}\right) ; 92$ (11); 64 (13); 63 (13).

6-Methyl-2-(1H-pyrrol-2-yl)benzo[d]oxazole (4d). The benzoxazole was purified by radial thin-layer chromatography on silica gel eluting with a petroleum ether/diethyl ether gradient $(80: 20 \rightarrow 50: 50)$ as white crystals, mp $168.0-170.0{ }^{\circ} \mathrm{C} .{ }^{1} \mathrm{H}$ NMR $\left(400 \mathrm{MHz}, \mathrm{CDCl}_{3}\right)$ $\delta_{\mathrm{H}}: 2.48(3 \mathrm{H}, \mathrm{s}) ; 6.34-6.37(1 \mathrm{H}, \mathrm{m}) ; 7.00-7.02(1 \mathrm{H}, \mathrm{m}) ; 7.06-7.08$ $(1 \mathrm{H}, \mathrm{m}) ; 7.12(1 \mathrm{H}, \mathrm{d}, J=7.9) ; 7.33(1 \mathrm{H}, \mathrm{s}) ; 7.52(1 \mathrm{H}, \mathrm{d}, J=8.2)$; $10.97(1 \mathrm{H}, \mathrm{s} \mathrm{br}) .{ }^{13} \mathrm{C}$ NMR $\left(101 \mathrm{MHz}, \mathrm{CDCl}_{3}\right) \delta_{\mathrm{C}}: 21.7\left(\mathrm{CH}_{3}\right) ; 110.6$ $(2 \mathrm{CH}) ; 112.9(\mathrm{CH}) ; 118.1(\mathrm{CH}) ; 119.9(\mathrm{C}) ; 122.9(\mathrm{CH}) ; 125.7$ $(\mathrm{CH}) ; 134.7(\mathrm{C}) ; 139.5(\mathrm{C}) ; 150.4(\mathrm{C}) ; 158.0(\mathrm{C}) .{ }^{1} \mathrm{H}-{ }^{13} \mathrm{C}$ HSQC $\operatorname{NMR}\left(\mathrm{CDCl}_{3}\right) \delta_{\mathrm{H} /} \delta_{\mathrm{C}}: 2.48 / 21.7 ; 6.35 / 110.6 ; 7.01 / 122.9 ; 7.07 / 112.9$; 7.12/125.7; 7.33/110.7; 7.52/118.1. ${ }^{1} \mathrm{H}-{ }^{13} \mathrm{C}$ HMBC NMR $\left(\mathrm{CDCl}_{3}\right)$ $\delta_{\mathrm{H} /} \delta_{\mathrm{C}}: 2.48 / 110.6 ; 2.48 / 125.7 ; 2.48 / 134.7 ; 6.35 / 119.9 ; 6.35 / 122.9 ;$ $7.01 / 110.6 ; 7.01 / 112.9 ; 7.01 / 119.9 ; 7.07 / 119.9 ; 7.07 / 122.9 ; 7.12 /$ $21.7 ; 7.12 / 110.7 ; 7.12 / 139.5 ; 7.33 / 21.7 ; 7.33 / 118.1 ; 7.33 / 125.7$; 7.33/139.5; 7.33/150.4; 7.52/110.7; 7.52/134.7; 7.52/150.4. GCMS (m/z): 199 (13); $198\left(100, \mathrm{M}^{+}\right) ; 197$ (50); 169 (14); 99 (8); 94 (8); 78 (15); 77 (9); 52 (7); 51 (8). HRMS (ESI) $\left[\mathrm{M}+\mathrm{H}^{+}\right]$calcd for $\mathrm{C}_{12} \mathrm{H}_{11} \mathrm{~N}_{2} \mathrm{O}^{+} 199.0866$, found 199.0886 .

6-Methoxy-2-(1H-pyrrol-2-yl)benzo[d]oxazole (4e). The benzoxazole was purified by radial thin-layer chromatography on silica gel eluting with a petroleum ether/diethyl ether gradient $(75: 25 \rightarrow 0: 100)$ as white crystals, mp $137.1-137.6{ }^{\circ} \mathrm{C} .{ }^{1} \mathrm{H}$ NMR $\left(400 \mathrm{MHz}, \mathrm{CDCl}_{3}\right)$ $\delta_{\mathrm{H}}$ : $3.87(3 \mathrm{H}, \mathrm{s}) ; 6.35-6.37(1 \mathrm{H}, \mathrm{m}) ; 6.92(1 \mathrm{H}, \mathrm{dd}, J=8.7,2.3)$; $7.00-7.04(2 \mathrm{H}, \mathrm{m}) ; 7.08(1 \mathrm{H}, \mathrm{d}, J=2.3) ; 7.53(1 \mathrm{H}, \mathrm{d}, J=8.7) ; 10.55$ $(1 \mathrm{H}, \mathrm{s} \mathrm{br}) .{ }^{13} \mathrm{C}$ NMR $\left(101 \mathrm{MHz}, \mathrm{CDCl}_{3}\right) \delta_{\mathrm{C}}: 55.9\left(\mathrm{OCH}_{3}\right) ; 95.7$ $(\mathrm{CH}) ; 110.6(\mathrm{CH}) ; 112.3(\mathrm{CH}) ; 112.4(\mathrm{CH}) ; 118.7(\mathrm{CH}) ; 120.0$ (C); $122.6(\mathrm{CH}) ; 135.4$ (C); 150.9 (C); 157.5 (C); 157.7 (C). ${ }^{1} \mathrm{H}-{ }^{1} \mathrm{H}$ COSY NMR $\left(\mathrm{CDCl}_{3}\right) \delta_{\mathrm{H}} / \delta_{\mathrm{H}}: 6.36 / 7.02 ; 6.92 / 7.08 ; 6.92 /$ 7.53. ${ }^{1} \mathrm{H}-{ }^{13} \mathrm{C}$ HSQC NMR $\left(\mathrm{CDCl}_{3}\right) \delta_{\mathrm{H} /} \delta_{\mathrm{C}}: 3.87 / 55.9 ; 6.36 / 110.6$; 6.92/112.3; 7.01/122.6; 7.03/112.4; 7.08/95.7; 7.53/118.7. ${ }^{1} \mathrm{H}-{ }^{13} \mathrm{C}$ HMBC NMR $\left(\mathrm{CDCl}_{3}\right) \delta_{\mathrm{H}} / \delta_{\mathrm{C}}: 3.87 / 157.7 ; 6.36 / 120.0 ; 6.36 / 122.6$; $6.92 / 95.7 ; 6.92 / 135.4 ; 6.92 / 157.7 ; 7.01 / 110.6 ; 7.01 / 112.3 ; 7.01 /$ $120.0 ; 7.03 / 122.5 ; 7.08 / 112.4 ; 7.08 / 135.4 ; 7.08 / 150.9 ; 7.08 / 157.7$; 7.53/95.7; 7.53/135.4; 7.53/150.9; 7.53/157.7. GC-MS $(\mathrm{m} / \mathrm{z}): 215$ (11); 214 (85, M+); 200 (13); 199 (100); 171 (9); 107 (11); 94 (22); 79 (34); 51 (22). HRMS (ESI) calcd for $\mathrm{C}_{12} \mathrm{H}_{11} \mathrm{~N}_{2} \mathrm{O}_{2}^{+}\left(\mathrm{M}+\mathrm{H}^{+}\right)$ 215.0815, found 215.0819 .

2-(1H-Pyrrol-2-yl)benzo[d]oxazole-6-carbonitrile (4f). The benzoxazole was purified by column chromatography on silica gel eluting with petroleum ether/diethyl ether gradient $(25: 75 \rightarrow 35: 65)$ and recrystallized from $\mathrm{CH}_{2} \mathrm{Cl}_{2}$ as colorless crystals, mp 198.0-199.0 ${ }^{\circ} \mathrm{C} .{ }^{1} \mathrm{H}$ NMR (400 MHz, DMSO- $\left.d_{6}\right) \delta_{\mathrm{H}}: 6.34-6.35$ (1H, m); 7.08 $(1 \mathrm{H}, \mathrm{s} \mathrm{br}) ; 7.21(1 \mathrm{H}, \mathrm{s} \mathrm{br}) ; 7.79(1 \mathrm{H}, \mathrm{d}, J=8.4) ; 7.82(1 \mathrm{H}, \mathrm{d}, J=8.4)$; 8.28 (1H, s br); 12.45 (1H, s br). ${ }^{13} \mathrm{C}$ NMR (101 MHz, DMSO- $\left.d_{6}\right)$ $\delta_{\mathrm{C}}: 105.8(\mathrm{C}) ; 110.8(\mathrm{CH}) ; 114.6(\mathrm{CH}) ; 114.7(\mathrm{CH}) ; 117.8(\mathrm{C})$; $119.0(\mathrm{CH}) ; 119.5(\mathrm{C}) ; 125.6(\mathrm{CH}) ; 129.3(\mathrm{CH}) ; 146.0(\mathrm{C}) ; 148.9$ (C); $160.4(\mathrm{C}) .{ }^{1} \mathrm{H}-{ }^{1} \mathrm{H}$ COSY NMR (DMSO- $\left.d_{6}\right) \delta_{\mathrm{H}} \delta_{\mathrm{H}}: 6.34 / 7.08$; 6.34/7.21; 7.79/7.82; 8.28/8.28. ${ }^{1} \mathrm{H}-{ }^{13} \mathrm{C}$ HSQC NMR (DMSO- $d_{6}$ ) $\delta_{\mathrm{H}} / \delta_{\mathrm{C}}: 6.34 / 110.8 ; 7.08 / 114.7 ; 7.21 / 125.6 ; 7.79 / 129.3 ; 7.82 / 119.0$; 
8.28/114.6. GC-MS (m/z): $210(14) ; 209\left(100, \mathrm{M}^{+}\right) ; 182(8) ; 154$ (6); 86 (6); 84 (8); 62 (6); 51 (6); 49 (11). HRMS (ESI) $\left[\mathrm{M}+\mathrm{H}^{+}\right]$ calcd for $\mathrm{C}_{12} \mathrm{H}_{8} \mathrm{~N}_{3} \mathrm{O}^{+} 210,0662$, found 210.0677 .

2-(1H-Pyrrol-2-yl)-6-(trifluoromethoxy)benzo[d]oxazole $(\mathbf{4 g})$. The benzoxazole was purified by radial thin-layer chromatography eluting with petroleum ether/diethyl ether $(90: 10 \rightarrow 50: 50)$ and was isolated as a white solid, mp 103.0-105.0 ${ }^{\circ} \mathrm{C} .{ }^{1} \mathrm{H}$ NMR $\left(400 \mathrm{MHz}, \mathrm{CDCl}_{3}\right) \delta_{\mathrm{H}}: 6.44-6.47(1 \mathrm{H}, \mathrm{m}) ; 7.12-7.15(1 \mathrm{H}, \mathrm{m})$; 7.15-7.16 (1H, m); 7.26-7.29 (1H, m); $7.49(1 \mathrm{H}, \mathrm{m}) ; 7.68(1 \mathrm{H}, \mathrm{d}$, $J=8.5) ; 9.71(1 \mathrm{H}, \mathrm{s}$ br $) .{ }^{19} \mathrm{~F}\left(377 \mathrm{MHz}, \mathrm{CDCl}_{3}\right) \delta_{\mathrm{F}}:-58.24 .{ }^{13} \mathrm{C}$ NMR $\left(101 \mathrm{MHz}, \mathrm{CDCl}_{3}\right) \delta_{\mathrm{C}}: 104.5(\mathrm{CH}) ; 111.2(\mathrm{CH}) ; 113.6(\mathrm{CH})$; $118.2(\mathrm{CH}) ; 119.0(\mathrm{CH}) ; 121.8(\mathrm{C}) ; 123.2(\mathrm{CH}) ; 140.6(\mathrm{C}) ; 145.8$ (C); 149.9 (C); $159.2(\mathrm{C}) .{ }^{1} \mathrm{H}-{ }^{1} \mathrm{H}$ COSY NMR $\left(\mathrm{CDCl}_{3}\right) \delta_{\mathrm{H}} \delta_{\mathrm{H}}$ : 6.45/7.12; 6.45/7.15; 7.27/7.49; 7.27/7.68. ${ }^{1} \mathrm{H}-{ }^{13} \mathrm{C}$ HSQC NMR $\left(\mathrm{CDCl}_{3}\right) \delta_{\mathrm{H}} / \delta_{\mathrm{C}}: 6.45 / 111.2 ; 7.12 / 123.2 ; 7.15 / 113.6 ; 7.27 / 118.2$; $7.49 / 104.5 ; 7.68 / 119.0 .{ }^{1} \mathrm{H}-{ }^{13} \mathrm{C}$ HMBC NMR $\left(\mathrm{CDCl}_{3}\right) \delta_{\mathrm{H}} / \delta_{\mathrm{C}}: 6.45 /$ 119.3 ; 6.45/123.2; 7.12/111.2; 7.12/113.6; 7.12/119.3; 7.15/123.2; $7.27 / 104.6 ; 7.27 / 140.6 ; 7.27 / 145.8 ; 7.45 / 149.9 ; 7.68 / 104.5 ; 7.68 /$ $145.8 ; 7.68 / 149.9 ; 7.68 / 119.0$. GC-MS $(\mathrm{m} / z): 269(12) ; 268(100$, $\mathrm{M}^{+}$); 200 (12); 199 (95); 94 (24); 79 (46); 69 (28); 51 (32). HRMS (ESI) $\left[\mathrm{M}+\mathrm{H}^{+}\right]$calcd $\mathrm{C}_{12} \mathrm{H}_{8} \mathrm{~F}_{3} \mathrm{~N}_{2} \mathrm{O}_{2}{ }^{+} 269.0532$, found 269.0558 .

Ethyl 2-(1H-Pyrrol-2-yl)benzo[d]oxazole-6-carboxylate (4h). The benzoxazole was purified by radial thin-layer chromatography on silica gel eluting with a petroleum ether/diethyl ether (90:10) and recrystallized in acetone as white needle crystals, $\mathrm{mp} 162.2-163.7^{\circ} \mathrm{C}$. ${ }^{1} \mathrm{H}$ NMR $\left(\mathrm{DMSO}-d_{6}\right) \delta_{\mathrm{H}}: 1.35(3 \mathrm{H}, \mathrm{t}, J=7.2) ; 4.34(2 \mathrm{H}, \mathrm{q}, J=7.2)$; 6.32-6.34 (1H, m); 7.05-7.07 (1H, m); 7.18-7.20 (1H, m); 7.75 $(1 \mathrm{H}, \mathrm{d}, J=8.2) ; 7.98(1 \mathrm{H}, \mathrm{dd}, J=8.2,1.1) ; 8.16(1 \mathrm{H}, \mathrm{d}, J=1.1)$; $12.40\left(1 \mathrm{H}, \mathrm{s}\right.$ br). ${ }^{13} \mathrm{C}$ NMR (DMSO-d 6$) \delta_{\mathrm{C}}: 14.7\left(\mathrm{CH}_{3}\right) ; 61.4\left(\mathrm{CH}_{2}\right)$; $111.1(\mathrm{CH}) ; 111.6(\mathrm{CH}) ; 114.7(\mathrm{CH}) ; 118.7(\mathrm{C}) ; 118.9(\mathrm{CH}) ; 125.7$ $(\mathrm{CH}) ; 126.2(\mathrm{C}) ; 126.6(\mathrm{CH}) ; 146.5(\mathrm{C}) ; 149.8(\mathrm{C}) ; 160.6(\mathrm{C})$; $165.8(\mathrm{C}) .{ }^{1} \mathrm{H}-{ }^{1} \mathrm{H}$ COSY NMR (DMSO- $d_{6}$ ) $\delta_{\mathrm{H}} / \delta_{\mathrm{H}}: 1.35 / 4.34 ; 6.33 /$ 7.06 ; 6.33/7.19; 6.33/12.40; 7.06/12.40; 7.19/12.40; 7.75/7.98; 7.75/ 8.16. ${ }^{1} \mathrm{H}-{ }^{13} \mathrm{C}$ HSQC NMR (DMSO- $d_{6}$ ) $\delta_{\mathrm{H}} / \delta_{\mathrm{C}}: 1.35 / 14.7 ; 4.34 / 61.4$; 6.33/111.1; 7.06/114.7; 7.19/125.7; 7.75/118.9; 7.98/126.6; 8.16/ 111.6. ${ }^{1} \mathrm{H}-{ }^{13} \mathrm{C}$ HMBC NMR (DMSO- $d_{6}$ ) $\delta_{\mathrm{H}} / \delta_{\mathrm{C}}: 1.35 / 61.4 ; 4.34 /$ $14.7 ; 4.34 / 165.8 ; 6.33 / 118.7 ; 6.33 / 125.7 ; 7.06 / 118.7 ; 7.06 / 125.7$; $7.19 / 111.1 ; 7.19 / 114.7 ; 7.19 / 118.7 ; 7.75 / 126.2 ; 7.75 / 149.8 ; 7.98 /$ $111.6 ; 7.98 / 146.5 ; 7.98 / 165.8 ; 7.98 / 118.9 ; 8.16 / 126.6 ; 8.16 / 146.5$; 8.16/149.8; 8.16/165.8. GC-MS (m/z): 257 (15); $256\left(99, \mathrm{M}^{+}\right) ; 228$ (51); 212 (16); 211 (100); 155 (44); 106 (12); 78 (15); 63 (13). HRMS (ESI) calcd for $\mathrm{C}_{14} \mathrm{H}_{12} \mathrm{~N}_{2} \mathrm{NaO}_{3}{ }^{+}\left(\mathrm{M}+\mathrm{Na}^{+}\right) 279.0740$, found 279.0766.

6-Chloro-2-(1H-pyrrol-2-yl)benzo[d]oxazole (4i). The benzoxazole was purified by radial thin-layer chromatography eluting with petroleum ether/diethyl ether $(90: 10 \rightarrow 50: 50)$ as a white solid, $\mathrm{mp}$ 220.0-223.0 ${ }^{\circ} \mathrm{C} .{ }^{1} \mathrm{H}$ NMR $\left(400 \mathrm{MHz} \mathrm{CDCl}_{3}\right) \delta_{\mathrm{H}}: 6.39(1 \mathrm{H}, \mathrm{m})$; 7.04-7.05 (1H, m); 7.08-7.09 (1H, m); $7.30(1 \mathrm{H}, \mathrm{dd}, J=8.4,1.9)$; $7.53-7.55(2 \mathrm{H}, \mathrm{m}) ; 10.10$ (1H, s br). ${ }^{13} \mathrm{C}$ NMR $\left(101 \mathrm{MHz}, \mathrm{CDCl}_{3}\right)$ $\delta_{\mathrm{C}}: 111.0(\mathrm{CH}) ; 111.1(\mathrm{CH}) ; 113.6(\mathrm{CH}) ; 119.2(\mathrm{CH}) ; 119.4(\mathrm{C})$; $123.3(\mathrm{CH}) ; 125.2(\mathrm{CH}) ; 129.8(\mathrm{C}) ; 140.6(\mathrm{C}) ; 150.3(\mathrm{C}) ; 158.7$ (C). ${ }^{1} \mathrm{H}-{ }^{1} \mathrm{H}$ COSY NMR $\left(\mathrm{CDCl}_{3}\right) \delta_{\mathrm{H}} \delta_{\mathrm{H}}: 6.39 / 7.05 ; 6.39 / 7.09 ; 7.30 /$ 7.54. ${ }^{1} \mathrm{H}-{ }^{13} \mathrm{C}$ HSQC NMR $\left(\mathrm{CDCl}_{3}\right) \delta_{\mathrm{H} /} \delta_{\mathrm{C}}: 6.39 / 111.0 ; 7.05 / 123.3$; 7.09/113.6; 7.30/125.2; 7.54/111.0; 7.54/119.2. ${ }^{1} \mathrm{H}-{ }^{13} \mathrm{C}$ HMBC NMR $\left(\mathrm{CDCl}_{3}\right) \delta_{\mathrm{H}} / \delta_{\mathrm{C}}: 6.39 / 119.4 ; 6.39 / 123.3 ; 6.39 / 113.6 ; 7.05 /$ 111.0; 7.05/113.6; 7.05/119.4; 7.09/123.3; 7.09/119.4; 7.30/111.1; 7.30/ $119.2 ; 7.30 / 129.8 ; 7.30 / 140.6 ; 7.54 / 125.2 ; 7.54 / 129.8 ; 7.54 / 140.6 ; 7.54 /$ 150.5. GC-MS (m/z): 220 (29); 219 (14); $218\left(100, \mathrm{M}^{+}\right) ; 191$ (12); 155 (22); 63 (31). HRMS (ESI) $\left[\mathrm{M}+\mathrm{H}^{+}\right]$calcd $\mathrm{C}_{11} \mathrm{H}_{8} \mathrm{ClN}_{2} \mathrm{O}^{+}$ 219.0320, found 219.0330 .

2-(1H-Indol-2-yl)benzo[d]oxazole (5a). ${ }^{51}$ The benzoxazole was purified by radial thin-layer chromatography eluting with petroleum ether/diethyl ether $(90: 10 \rightarrow 50: 50)$ and was isolated as white solid, $\mathrm{mp} 245.0-246.0{ }^{\circ} \mathrm{C} .{ }^{1} \mathrm{H}$ NMR $\left(400 \mathrm{MHz}, \mathrm{CDCl}_{3}\right) \delta_{\mathrm{H}}: 7.18(1 \mathrm{H}, \mathrm{m})$; $7.31(1 \mathrm{H}, \mathrm{m}) ; 7.37(2 \mathrm{H}, \mathrm{m}) ; 7.41(2 \mathrm{H}, \mathrm{m}) ; 7.61(1 \mathrm{H}, \mathrm{m}) ; 7.73(2 \mathrm{H}$, m); $9.76(1 \mathrm{H}, \mathrm{s} \mathrm{br}) .{ }^{13} \mathrm{C} \mathrm{NMR}\left(101 \mathrm{MHz}, \mathrm{CDCl}_{3}\right) \delta_{\mathrm{C}}: 106.5(\mathrm{CH})$; $110.6(\mathrm{CH}) ; 111.7(\mathrm{CH}) ; 119.6(\mathrm{CH}) ; 120.9(\mathrm{CH}) ; 122.0(\mathrm{CH})$; $124.8(\mathrm{C}) ; 124.9(\mathrm{CH}) ; 124.9(\mathrm{CH}) ; 125.2(\mathrm{CH}) ; 128.1(\mathrm{C}) ; 137.5$ (C); 141.6 (C); $150.6(\mathrm{C}) ; 157.9(\mathrm{C}) .{ }^{1} \mathrm{H}-{ }^{1} \mathrm{H}$ COSY NMR $\left(\mathrm{CDCl}_{3}\right)$ $\delta_{\mathrm{H} /} \delta_{\mathrm{H}}: 7.18 / 7.31 ; 7.18 / 7.73 ; 7.31 / 7.41 ; 7.37 / 7.61 ; 7.37 / 7.73 .{ }^{1} \mathrm{H}-{ }^{13} \mathrm{C}$
HSQC NMR $\left(\mathrm{CDCl}_{3}\right) \delta_{\mathrm{H} /} \delta_{\mathrm{C}}: 7.18 / 120.9 ; 7.31 / 124.9 ; 7.37 / 124.9 ;$ $7.37 / 125.2 ; 7.41 / 106.5 ; 7.41 / 111.7 ; 7.61 / 110.6 ; 7.73 / 119.6 ; 7.73 /$ 122.0. ${ }^{1} \mathrm{H}-{ }^{13} \mathrm{C}$ HMBC NMR $\left(\mathrm{CDCl}_{3}\right) \delta_{\mathrm{H}} \delta_{\mathrm{C}}: 7.18 / 111.7 ; 7.18 / 128.1$; $7.31 / 110.6 ; 7.31 / 122.0 ; 7.31 / 137.5 ; 7.37 / 119.6 ; 7.37 / 141.6 ; 7.41 /$ $120.9 ; 7.41 / 124.8 ; 7.41 / 128.1 ; 7.41 / 137.5 ; 7.61 / 124.9 ; 7.61 / 141.6$; $7.73 / 106.5 ; 7.73 / 124.9 ; 7.73 / 137.5 ; 7.73 / 141.6 ; 7.73 / 150.6$. GC-MS $(\mathrm{m} / z): 235$ (17); $234\left(100, \mathrm{M}^{+}\right) ; 205$ (13); 117 (13). HRMS (ESI) $\left[\mathrm{M}+\mathrm{H}^{+}\right]$calcd. $\mathrm{C}_{15} \mathrm{H}_{11} \mathrm{~N}_{2} \mathrm{O}^{+} 235.0866$, found 235.0883 .

2-(1H-Indol-2-yl)-6-methylbenzo[d]oxazole (5b). The benzoxazole was purified by radial thin-layer chromatography on silica gel eluting with a petroleum ether/diethyl ether (80:20) and was isolated as white solid, $\mathrm{mp} 200-201{ }^{\circ} \mathrm{C} .{ }^{1} \mathrm{H}$ NMR $\left(400 \mathrm{MHz}\right.$, acetone- $\left.d_{6}\right) \delta_{\mathrm{H}}$ : $2.50(3 \mathrm{H}, \mathrm{s}) ; 7.14(1 \mathrm{H}, \mathrm{ddd}, J=8.0,7.0,1.0) ; 7.23(1 \mathrm{H}, \mathrm{ddd}, J=8.1$, $1.5,0.6)$; $7.29(1 \mathrm{H}$, ddd $J=8.2,7.0,1.1) ; 7.34(1 \mathrm{H}, \mathrm{dd}, J=2.2,0.9)$; $7.50-7.51(1 \mathrm{H}, \mathrm{m}) ; 7.59-7.62(2 \mathrm{H} ; \mathrm{m}) ; 7.71-7.73(1 \mathrm{H}, \mathrm{m}) ; 11.20$ $(1 \mathrm{H}, \mathrm{s}) .{ }^{13} \mathrm{C}$ NMR $\left(101 \mathrm{MHz}\right.$, acetone- $\left.d_{6}\right) \delta_{\mathrm{C}}: 21.7\left(\mathrm{CH}_{3}\right) ; 106.1$ $(\mathrm{CH}) ; 111.5(\mathrm{CH}) ; 113.0(\mathrm{CH}) ; 119.9(\mathrm{CH}) ; 121.4(\mathrm{CH}) ; 122.4$ $(\mathrm{CH}) ; 125.2(\mathrm{CH}) ; 126.0(\mathrm{C}) ; 126.8(\mathrm{CH}) ; 129.0(\mathrm{C}) ; 136.5(\mathrm{C})$; 139.0 (C); 140.8 (C); 151.7 (C); 158.2 (C). ${ }^{1} \mathrm{H}-{ }^{1} \mathrm{H}$ COSY NMR (acetone- $d_{6}$ ) $\delta_{\mathrm{H}} \delta_{\mathrm{H}}: 2.50 / 7.5 ; 7.14 / 7.29 ; 7.14 / 7.72 ; 7.22 / 7.60 ; 7.29 /$ 7.60. ${ }^{1} \mathrm{H}-{ }^{13} \mathrm{C}$ HSQC NMR (acetone- $d_{6}$ ) $\delta_{\mathrm{H} /} \delta_{\mathrm{C}}: 2.53 / 21.7 ; 7.12 /$ $121.4 ; 7.22 / 126.8 ; 7.28 / 125.2 ; 7.32 / 106.1 ; 7.51 / 111.5 ; 7.60 / 119.9$; 7.60/113.0; 7.71/122.4. ${ }^{1} \mathrm{H}-{ }^{13} \mathrm{C}$ HMBC NMR (acetone- $d_{6}$ ) $\delta_{\mathrm{H} /} \delta_{\mathrm{C}}$ : $2.50 / 111.5 ; 2.50 / 126.8 ; 2.50 / 136.5 ; 7.14 / 113.0 ; 7.14 / 129.0 ; 7.23 /$ $111.5 ; 7.23 / 140.8 ; 7.29 / 122.4 ; 7.29 / 139.0 ; 7.34 / 126.0 ; 7.34 / 129.0$; $7.51 / 126.8 ; 7.51 / 140.8 ; 7.51 / 151.7 ; 7.60 / 121.4 ; 7.60 / 129.0 ; 7.60 /$ $136.5 ; 7.60 / 151.7 ; 7.72 / 125.2 ; 7.72 / 139.0$. GC-MS $(\mathrm{m} / z): 250(2)$; 249 (16); $248\left(100, \mathrm{M}^{+}\right) ; 247$ (26); 142 (17); 123 (17); 115 (13); 89 (16); 78 (17); $77(20) ; 52(13) ; 51(16)$. HRMS (ESI) $\left[\mathrm{M}+\mathrm{Na}^{+}\right]$ calcd $\mathrm{C}_{16} \mathrm{H}_{12} \mathrm{~N}_{2} \mathrm{NaO}^{+} 271.0842$, found 271.0864 .

2-(1H-Indol-2-yl)-6-methoxybenzo[d]oxazole (5c). The benzoxazole was purified by radial thin-layer chromatography on silica gel eluting with a petroleum ether/diethyl ether gradient $(80: 20 \rightarrow 0: 100)$ and was isolated as yellow pale solid, mp $162.5-164.0{ }^{\circ} \mathrm{C} .{ }^{1} \mathrm{H}$ NMR $\left(400 \mathrm{MHz}\right.$, acetone- $\left.d_{6}\right) \delta_{\mathrm{H}}: 3.90(3 \mathrm{H}, \mathrm{s}) ; 7.00(1 \mathrm{H}, \mathrm{dd}, J=8.7,2.4)$; 7.11-7.15 (1H, m); 7.26-7.30 (3H, m); 7.58-7.61 (2H, m); 7.71 $(1 \mathrm{H}, \mathrm{d}, J=8.0)$; $11.15(1 \mathrm{H}, \mathrm{s} \mathrm{br}) .{ }^{13} \mathrm{C}$ NMR $\left(101 \mathrm{MHz}\right.$, acetone- $\left.d_{6}\right)$ $\delta_{\mathrm{C}}$ : $56.4\left(\mathrm{CH}_{3}\right)$; $96.3(\mathrm{CH}) ; 105.7(\mathrm{CH}) ; 113.0(\mathrm{CH}) ; 113.9(\mathrm{CH})$; $120.5(\mathrm{CH}) ; 121.4(\mathrm{CH}) ; 122.4(\mathrm{CH}) ; 125.1(\mathrm{CH}) ; 126.1(\mathrm{C}) ; 129.2$ (C); 136.6 (C); 139.0 (C); 152.4 (C); 157.8 (C); 159.6 (C). ${ }^{1} \mathrm{H}-{ }^{1} \mathrm{H}$ COSY NMR (acetone- $\left.d_{6}\right) \delta_{\mathrm{H}} / \delta_{\mathrm{H}}: 7.00 / 7.28 ; 7.00 / 7.59 ; 7.13 / 7.28$; $7.13 / 7.71 ; 7.28 / 7.59 .{ }^{1} \mathrm{H}-{ }^{13} \mathrm{C}$ HSQC NMR (acetone- $d_{6}$ ) $\delta_{\mathrm{H}} / \delta_{\mathrm{C}}: 3.90 /$ 56.4; 7.00/113.9; 7.13/121.4; 7.28/96.3; 7.28/105.7; 7.28/125.1; 7.59/113.0; 7.59/120.5; 7.71/122.4. ${ }^{1} \mathrm{H}-{ }^{13} \mathrm{C}$ HMBC NMR (acetone- $\left.d_{6}\right) \delta_{\mathrm{H}} / \delta_{\mathrm{C}}: 3.90 / 159.6 ; 7.00 / 96.3 ; 7.00 / 136.6 ; 7.00 / 159.6 ; 7.13 /$ $113.0 ; 7.13 / 129.2 ; 7.28 / 113.9 ; 7.28 / 122.4 ; 7.28 / 126.1 ; 7.28 / 129.2$; $7.28 / 136.6 ; 7.28 / 139.0 ; 7.28 / 152.4 ; 7.28 / 159.6 ; 7.59 / 121.4 ; 7.59 /$ $129.2 ; 7.59 / 152.4 ; 7.59 / 159.6 ; 7.71 / 125.1 ; 7.71 / 125.1 ; 7.71 / 139.0$. GC-MS (m/z): $265(17) ; 264\left(100, \mathrm{M}^{+}\right) ; 250(14) ; 249$ (93); 144 (9); 132 (12); 79 (18). HRMS (ESI) $\left[\mathrm{M}+\mathrm{H}^{+}\right]$calcd $\mathrm{C}_{16} \mathrm{H}_{13} \mathrm{~N}_{2} \mathrm{O}_{2}{ }^{+}$ 265.0972 , found 265.1000 .

2-(1H-Indol-2-yl)-6-(trifluoromethoxy)benzo[d]oxazole (5d). The benzoxazole was purified by column chromatography on silica gel eluting with petroleum ether $/ \mathrm{CH}_{2} \mathrm{Cl}_{2}$ gradient $(50: 50 \rightarrow 0: 100)$ as white crystals, mp $174-175^{\circ} \mathrm{C} .{ }^{1} \mathrm{H}$ NMR $\left(400 \mathrm{MHz}, \mathrm{CDCl}_{3}\right) \delta_{\mathrm{H}}: 7.19$ $(1 \mathrm{H}, \mathrm{ddd}, J=8.1,7.0,1.2) ; 7.24-7.26(1 \mathrm{H}, \mathrm{m}) ; 7.32(1 \mathrm{H}, \mathrm{ddd}, J=8.1$, $6.9,1.2) ; 7.39-7.43(2 \mathrm{H}, \mathrm{m}) ; 7.50(1 \mathrm{H}, \mathrm{d}, J=1.2) ; 7.69(1 \mathrm{H}, \mathrm{d}, J=$ 8.4); 7.73 (1H, dd; $J=8.0,0.8) ; 9.52(1 \mathrm{H}, \mathrm{s} \mathrm{br}) .{ }^{19} \mathrm{~F}$ NMR $(377 \mathrm{MHz}$, $\left.\mathrm{CDCl}_{3}\right) \delta_{\mathrm{F}}:-58.19 .{ }^{13} \mathrm{C} \mathrm{NMR}\left(101 \mathrm{MHz}, \mathrm{CDCl}_{3}\right) \delta_{\mathrm{C}}: 104.7(\mathrm{CH})$; $107.1(\mathrm{CH})$; $111.7(\mathrm{CH}) ; 118.6(\mathrm{CH}) ; 119.9(\mathrm{CH}) ; 120.6\left(\mathrm{OCF}_{3}, \mathrm{~d}\right.$, $J=256) ; 121.1(\mathrm{CH}) ; 122.2(\mathrm{CH}) ; 124.1(\mathrm{C}) ; 125.3(\mathrm{CH}) ; 128.1$ (C); 137.6 (C); 140.4 (C); 146.4 (C); 150.4 (C); 159.2 (C). ${ }^{1}{ }^{1}-{ }^{1} \mathrm{H}$ COSY NMR $\left(\mathrm{CDCl}_{3}\right) \delta_{\mathrm{H}} / \delta_{\mathrm{H}}: 7.19 / 7.32 ; 7.19 / 7.73 ; 7.25 / 7.50 ; 7.25 /$ 7.69; 7.32/7.41; 7.41/9.52. ${ }^{1} \mathrm{H}-{ }^{13} \mathrm{C}$ HSQC NMR $\left(\mathrm{CDCl}_{3}\right) \delta_{\mathrm{H}} / \delta_{\mathrm{C}}$ : $7.19 / 121.1 ; 7.25 / 118.6 ; 7.32 / 125.3 ; 7.41 / 107.1 ; 7.41 / 111.7 ; 7.50 /$ 104.7; 7.69/119.9; 7.73/122.2. ${ }^{1} \mathrm{H}-{ }^{13} \mathrm{C}$ HMBC NMR $\left(\mathrm{CDCl}_{3}\right) \delta_{\mathrm{H}} /$ $\delta_{\mathrm{C}}: 7.19 / 111.7 ; 7.19 / 128.1 ; 7.25 / 140.4 ; 7.25 / 146.4 ; 7.32 / 122.2 ; 7.32 /$ $137.6 ; 7.41 / 124.1 ; 7.41 / 137.6 ; 7.41 / 121.1 ; 7.41 / 128.1 ; 7.50 / 118.6$; 7.50/140.4; 7.50/146.4; 7.50/150.4; 7.69/146.4; 7.69/150.4; 7.73/107.1; 
7.73/125.3; 7.73/137.6. HRMS (ESI) $\left[\mathrm{M}+\mathrm{H}^{+}\right]$calcd $\mathrm{C}_{16} \mathrm{H}_{10} \mathrm{~F}_{3} \mathrm{~N}_{2} \mathrm{O}_{2}{ }^{+}$ 319.0689, found 319.0692.

Ethyl 2-(1H-Indol-2-yl)benzo[d]oxazole-6-carboxylate (5e). The benzoxazole was purified by column chromatography on silica gel eluting with a petroleum ether/diethyl ether gradient $(100: 0 \rightarrow 50: 50)$ as orange solid serous. ${ }^{1} \mathrm{H}$ NMR $\left(400 \mathrm{MHz}, \mathrm{CDCl}_{3}\right) \delta_{\mathrm{H}}: 1.44(3 \mathrm{H}, \mathrm{t}$, $J=7.2) ; 4.44(2 \mathrm{H}, \mathrm{q}, J=7.1) ; 7.18-7.22(1 \mathrm{H}, \mathrm{m}) ; 7.33(1 \mathrm{H}, \mathrm{m})$; 7.44-7.48 (2H, m); 7.73-7.76 (2H, m); $8.12(1 \mathrm{H}, \mathrm{dd}, J=8.4,1.5)$; $8.28(1 \mathrm{H}, \mathrm{m}) ; 9.32(1 \mathrm{H}, \mathrm{s} \mathrm{br}) .{ }^{13} \mathrm{C} \mathrm{NMR}\left(101 \mathrm{MHz}, \mathrm{CDCl}_{3}\right) \delta_{\mathrm{C}}: 14.4$ $\left(\mathrm{CH}_{3}\right) ; 61.3\left(\mathrm{CH}_{2}\right) ; 107.6(\mathrm{CH}) ; 111.7(\mathrm{CH}) ; 112.1(\mathrm{CH}) ; 119.1$ $(\mathrm{CH}) ; 121.2(\mathrm{CH}) ; 122.2(\mathrm{CH}) ; 124.1(\mathrm{C}) ; 125.5(\mathrm{CH}) ; 126.7$ (CH); 127.5 (C), $128.1(\mathrm{C}) ; 137.6(\mathrm{C}) ; 145.6(\mathrm{C}) ; 150.3(\mathrm{C}) ; 160.0$ (C); $166.1(\mathrm{C}) .{ }^{1} \mathrm{H}-{ }^{1} \mathrm{H}$ COSY NMR $\left(\mathrm{CDCl}_{3}\right) \delta_{\mathrm{H}} / \delta_{\mathrm{H}}: 1.44 / 4.44$; $7.20 / 7.35 ; 7.20 / 7.73 ; 7.35 / 7.46 ; 7.46 / 9.32 ; 7.73 / 8.12 ; 7.76 / 8.12$. ${ }^{1} \mathrm{H}-{ }^{13} \mathrm{C}$ HSQC NMR $\left(\mathrm{CDCl}_{3}\right) \delta_{\mathrm{H}} / \delta_{\mathrm{C}}: 1.44 / 14.4 ; 4.44 / 61.3 ; 7.20 /$ $121.2 ; 7.35 / 125.5 ; 7.46 / 107.6 ; 7.46 / 111.7 ; 7.73 / 119.1 ; 7.76 / 122.2$; 8.12/126.7; 8.28/112.1. ${ }^{1} \mathrm{H}-{ }^{13} \mathrm{C}$ HMBC NMR $\left(\mathrm{CDCl}_{3}\right) \delta_{\mathrm{H}} / \delta_{\mathrm{C}}: 1.44 /$ $61.3 ; 4.44 / 14.4 ; 4.44 / 166.1 ; 7.20 / 111.7 ; 7.20 / 128.1 ; 7.35 / 122.2$; $7.35 / 137.7 ; 7.46 / 121.2) ; 7.46 / 124.2 ; 7.46 / 128.1 ; 7.46 / 137.7$. GCMS (m/z): $306\left(100, \mathrm{M}^{+}\right) ; 279$ (11); 278 (48); 261 (19); 233 (11); 205 (28); 102 (17). HRMS (ESI) $\left[\mathrm{M}+\mathrm{H}^{+}\right]$calcd $\mathrm{C}_{18} \mathrm{H}_{15} \mathrm{~N}_{2} \mathrm{O}_{3}{ }^{+}$ 307.1077 , found 307.1099 .

6-Chloro-2-(1H-indol-2-yl)benzo[d]oxazole (5f). The benzoxazole was purified by radial thin-layer chromatography eluting with petroleum ether/diethyl ether (90:10 $\rightarrow$ 50:50) and was isolated as white solid, mp $185.0-186.0{ }^{\circ} \mathrm{C} .{ }^{1} \mathrm{H}$ NMR $\left(400 \mathrm{MHz}, \mathrm{CDCl}_{3}\right) \delta_{\mathrm{H}}$ : 7.19-7.21 (1H, m); 7.32-7.36 (2H, m); 7.39-7.43 (2H, m); 7.60$7.61(2 \mathrm{H}, \mathrm{m}) ; 7.73(1 \mathrm{H}, \mathrm{dd}, J=8.0,0.7) ; 9.53(1 \mathrm{H}, \mathrm{s} \mathrm{br}) .{ }^{13} \mathrm{C}$ NMR $\left(101 \mathrm{MHz}, \mathrm{CDCl}_{3}\right) \delta_{\mathrm{C}}: 107.0(\mathrm{CH}) ; 111.3(\mathrm{CH}) ; 111.7(\mathrm{CH}) ; 120.0$ $(\mathrm{CH}) ; 121.1(\mathrm{CH}) ; 122.1(\mathrm{CH}) ; 124.2(\mathrm{C}) ; 125.2(\mathrm{CH}) ; 125.6$ (CH); $128.1(\mathrm{C}) ; 130.8(\mathrm{C}) ; 137.6(\mathrm{C}) ; 140.5(\mathrm{C}) ; 150.8(\mathrm{C}) ; 158.4$ (C). ${ }^{1} \mathrm{H}-{ }^{1} \mathrm{H}$ COSY NMR $\left(\mathrm{CDCl}_{3}\right) \delta_{\mathrm{H}} \delta_{\mathrm{H}}: 7.19 / 7.33 ; 7.19 / 7.73 ; 7.33 /$ 7.40; 7.33/7.61. ${ }^{1} \mathrm{H}-{ }^{13} \mathrm{C}$ HSQC NMR $\left(\mathrm{CDCl}_{3}\right) \delta_{\mathrm{H}} / \delta_{\mathrm{C}}: 7.19 / 121.1$; $7.33 / 125.2 ; 7.33 / 125.6 ; 7.40 / 107.0 ; 7.40 / 111.7 ; 7.61 / 111.3 ; 7.61 /$ 120.0; 7.73/122.1. ${ }^{1} \mathrm{H}-{ }^{13} \mathrm{C}$ HMBC NMR $\left(\mathrm{CDCl}_{3}\right) \delta_{\mathrm{H}} / \delta_{\mathrm{C}}: 7.19 /$ $111.7 ; 7.19 / 128.1 ; 7.33 / 111.3 ; 7.33 / 122.1 ; 7.33 / 137.6 ; 7.33 / 140.5$; $7.40 / 121.1 ; 7.40 / 124.2 ; 7.40 / 128.1 ; 7.40 / 137.6 ; 7.61 / 111.3 ; 7.61 /$ $130.8 ; 7.61 / 140.5 ; 7.61 / 150.8 ; 7.73 / 107.0 ; 7.73 / 125.2 ; 7.73 / 128.1$; 7.73/137.6. GC-MS (m/z): $270(33) ; 269(18) ; 268\left(100, \mathrm{M}^{+}\right) ; 205$ (15); 134 (15); 115 (12); 89 (11); 63 (21). HRMS (ESI) $\left[\mathrm{M}+\mathrm{H}^{+}\right]$ calcd. for $\mathrm{C}_{15} \mathrm{H}_{10} \mathrm{ClN}_{2} \mathrm{O}^{+} 269.0476$, found 269.0451 .

2-(1H-Indol-3-yl)benzo[d]oxazole (6a). The benzoxazole was purified by radial thin-layer chromatography on silica gel eluting with a petroleum ether/diethyl ether gradient $(50: 50 \rightarrow 0: 100)$ and was isolated as white solid, $\mathrm{mp} 190.0-191.0{ }^{\circ} \mathrm{C}$ (lit. $\left.190-191{ }^{\circ} \mathrm{C}\right) .{ }^{52}{ }^{1} \mathrm{H}$ NMR $\left(400 \mathrm{MHz}, \mathrm{CDCl}_{3}\right) \delta_{\mathrm{H}}: 7.35-7.38(4 \mathrm{H}, \mathrm{m}) ; 7.46-7.48(1 \mathrm{H}$, m); 7.56-7.58 (1H, m); 7.74-7.77 $(1 \mathrm{H}, \mathrm{m}) ; 8.09(1 \mathrm{H}, \mathrm{d}, J=2.9)$; $8.50-8.52(1 \mathrm{H}, \mathrm{m}) ; 8.88(1 \mathrm{H}, \mathrm{s} \mathrm{br}) .{ }^{13} \mathrm{C} \mathrm{NMR}\left(101 \mathrm{MHz}, \mathrm{CDCl}_{3}\right) \delta_{\mathrm{C}}$ : $105.5(\mathrm{C}) ; 110.1(\mathrm{CH}) ; 111.6(\mathrm{CH}) ; 119.1(\mathrm{CH}) ; 121.6(\mathrm{CH}) ; 122.0$ $(\mathrm{CH}) ; 123.6(\mathrm{CH}) ; 124.0(\mathrm{CH}) ; 124.2(\mathrm{CH}) ; 125.0(\mathrm{C}) ; 127.5$ (CH); 136.3 (C); 142.3 (C); 150.0 (C); 161.3 (C). ${ }^{1} \mathrm{H}-{ }^{1} \mathrm{H}$ COSY NMR $\left(\mathrm{CDCl}_{3}\right) \delta_{\mathrm{H}} / \delta_{\mathrm{H}}: 7.35 / 7.47 ; 7.35 / 7.57 ; 7.35 / 7.76 ; 7.73 / 8.51$; 8.09/8.88. ${ }^{1} \mathrm{H}-{ }^{13} \mathrm{C}$ HSQC NMR $\left(\mathrm{CDCl}_{3}\right) \delta_{\mathrm{H}} / \delta_{\mathrm{C}}: 7.35 / 122.0 ; 7.35 /$ 123.6; 7.35/124.0; 7.35/124.2; 7.47/111.6; 7.57/110.1; 7.76/119.1; 8.09/127.5; 8.51/121.6. ${ }^{1} \mathrm{H}-{ }^{13} \mathrm{C}$ HMBC NMR $\left(\mathrm{CDCl}_{3}\right) \delta_{\mathrm{H}} / \delta_{\mathrm{C}}: 7.35 /$ $110.1 ; 7.35 / 111.6 ; 7.35 / 119.1 ; 7.35 / 121.6 ; 7.35 / 125.0 ; 7.35 / 136.3$; $7.35 / 142.3 ; 7.35 / 150.0 ; 7.47 / 122.0 ; 7.47 / 125.0 ; 7.57 / 124.0 ; 7.57 /$ $142.3 ; 7.57 / 150.0 ; 7.76 / 124.2 ; 7.76 / 150.0 ; 8.09 / 105.5 ; 8.09 / 125.0$; $8.09 / 127.5 ; 8.09 / 136.3 ; 8.09 / 161.3 ; 8.51 / 105.5 ; 8.51 / 123.6 ; 8.51 /$ 136.3. GC-MS ( $m / z)$ : $235(16), 234\left(100, \mathrm{M}^{+}\right)$. HRMS (ESI) $\left[\mathrm{M}+\mathrm{H}^{+}\right]$ calcd $\mathrm{C}_{15} \mathrm{H}_{11} \mathrm{~N}_{2} \mathrm{O}^{+} 235.0866$, found 235.0879 .

2-(1H-Indol-3-yl)-6-methylbenzo[d] oxazole (6b). The benzoxazole was purified by radial thin-layer chromatography eluting with a petroleum ether/diethyl ether gradient $(80: 20 \rightarrow 0: 100)$ and was isolated as white solid, $\mathrm{mp} 235.5-237.3{ }^{\circ} \mathrm{C} .{ }^{1} \mathrm{H}$ NMR $(400 \mathrm{MHz}$, acetone- $\left.d_{6}\right) \delta_{\mathrm{H}}: 2.48(3 \mathrm{H}, \mathrm{s}) ; 7.17(1 \mathrm{H}, \mathrm{d}, J=8.0) ; 7.27-7.31(2 \mathrm{H}$, m); $7.44(1 \mathrm{H}, \mathrm{m}) ; 7.55-7.59(2 \mathrm{H}, \mathrm{m}) ; 8.22-8.23(1 \mathrm{H}, \mathrm{m}) ; 8.45-8.47$ $(1 \mathrm{H}, \mathrm{m}) ; 11.08(1 \mathrm{H}, \mathrm{s} \mathrm{br}) .{ }^{13} \mathrm{C}$ NMR $\left(101 \mathrm{MHz}\right.$, acetone- $\left.d_{6}\right) \delta_{\mathrm{C}}: 21.6$ $\left(\mathrm{CH}_{3}\right) ; 105.2(\mathrm{C}) ; 111.0(\mathrm{CH}) ; 113.0(\mathrm{CH}) ; 119.1(\mathrm{CH}) ; 122.0$ $(\mathrm{CH}) ; 122.1(\mathrm{CH}) ; 123.8(\mathrm{CH}) ; 126.0(\mathrm{CH}) ; 126.1(\mathrm{CH}), 129.1$
(CH); 134.9 (C); 137.9 (C); 141.5 (C); 150.9 (C); 161.6 (C). ${ }^{1} \mathrm{H}-{ }^{1} \mathrm{H}$ COSY NMR (acetone- $d_{6}$ ) $\delta_{\mathrm{H}} / \delta_{\mathrm{H}}: 7.17 / 7.57 ; 7.28 / 7.57 ; 7.28 /$ 8.46. ${ }^{1} \mathrm{H}-{ }^{13} \mathrm{C}$ HSQC NMR (acetone- $d_{6}$ ) $\delta_{\mathrm{H}} / \delta_{\mathrm{C}}: 2.48 / 21.6 ; 7.17 /$ $126.0 ; 7.28 / 122.1 ; 7.28 / 123.8 ; 7.44 / 111.0 ; 7.57 / 113.0 ; 7.57 / 119.1$; 8.22/129.1; 8.46/122.0. ${ }^{1} \mathrm{H}-{ }^{13} \mathrm{C}$ HMBC NMR (acetone- $d_{6}$ ) $\delta_{\mathrm{H}} / \delta_{\mathrm{C}}$ : $2.48 / 111.0 ; 2.48 / 126.0 ; 2.48 / 134.9 ; 7.17 / 21.6 ; 7.17 / 111.0 ; 7.17 /$ $141.5 ; 7.28 / 113.0 ; 7.28 / 122.0 ; 7.28 / 126.1 ; 7.28 / 137.9 ; 7.44 / 21.6$; $7.44 / 126.0 ; 7.44 / 141.5 ; 7.44 / 150.9 ; 7.57 / 122.1 ; 7.57 / 126.1 ; 7.57 /$ $134.9 ; 7.57 / 150.9 ; 8.22 / 105.2 ; 8.22 / 126.1 ; 8.22 / 137.9 ; 8.46 / 123.8$; 8.46/129.1; 8.46/137.9. GC-MS ( $m / z): 250$ (2); 249 (17); 248 (100, $\left.\mathrm{M}^{+}\right) ; 247$ (29); 219 (10); 142 (10); 124 (13). HRMS (ESI) $\left[\mathrm{M}+\mathrm{H}^{+}\right]$ calcd $\mathrm{C}_{16} \mathrm{H}_{13} \mathrm{~N}_{2} \mathrm{O}^{+} 249.1022$, found 249.1013 .

$\mathrm{N}$-Phenyl-1H-pyrrole-2-carboxamide (7a). The amide was purified by radial thin-layer chromatography eluting with petroleum ether/diethyl ether $(90: 10 \rightarrow 50: 50)$ and was isolated as a white solid, mp 181.0-182.0 ${ }^{\circ} \mathrm{C} .{ }^{1} \mathrm{H}$ NMR $\left(400 \mathrm{MHz}, \mathrm{CDCl}_{3}\right) \delta_{\mathrm{H}}$ : 6.29-6.31 $(1 \mathrm{H}, \mathrm{m}), 6.71(1 \mathrm{H}, \mathrm{m}) ; 6.99-7.00(1 \mathrm{H}, \mathrm{m}) ; 7.11-7.15(1 \mathrm{H}, \mathrm{m})$; 7.34-7.38 (2H, m); 7.55 (1H, s br); 7.59-7.61 (2H, m); $9.54(1 \mathrm{H}, \mathrm{s}$ br). ${ }^{13} \mathrm{C}$ NMR $\left(101 \mathrm{MHz}, \mathrm{CDCl}_{3}\right) \delta_{\mathrm{C}}: 109.4(\mathrm{CH}) ; 110.2(\mathrm{CH})$; $120.0(\mathrm{CH}) ; 122.3(\mathrm{CH}) ; 124.2(\mathrm{CH}) ; 126.0(\mathrm{C}) ; 129.1(\mathrm{CH}) ; 137.8$ (C); 159.0 (C). ${ }^{13} \mathrm{C}$ DEPT-135 NMR: 109.4; 110.2; 120.0; 122.3; 124.2; 129.1. GC-MS (m/z): $186\left(25, \mathrm{M}^{+}\right)$; 94 (47); 93 (100); 66 (31). HRMS (ESI) calcd. for $\mathrm{C}_{11} \mathrm{H}_{11} \mathrm{~N}_{2} \mathrm{O}^{+}\left[\mathrm{M}+\mathrm{H}^{+}\right]$187.0866, found 187.0866.

$\mathrm{N}$-(p-Tolyl)-1H-pyrrole-2-carboxamide (7d). The amide was purified by radial thin-layer chromatography on silica gel eluting with a petroleum ether/diethyl ether gradient $(80: 20 \rightarrow 50: 50)$ as white crystals. ${ }^{1} \mathrm{H}$ NMR $\left(400 \mathrm{MHz}, \mathrm{CDCl}_{3}\right) \delta_{\mathrm{H}}: 2.33(3 \mathrm{H}, \mathrm{s}) ; 6.27-6.30$ $(1 \mathrm{H}, \mathrm{m}) ; 6.68(1 \mathrm{H}, \mathrm{s}) ; 6.97-6.98(1 \mathrm{H}, \mathrm{m}) ; 7.15(1 \mathrm{H}, \mathrm{s}) ; 7.17(1 \mathrm{H}, \mathrm{s})$; $7.47(2 \mathrm{H}, \mathrm{d}, J=8.5) ; 7.51(1 \mathrm{H}, \mathrm{s} \mathrm{br}) ; 9.62(1 \mathrm{H}, \mathrm{s} \mathrm{br}) .{ }^{13} \mathrm{C}$ NMR $(101$ $\left.\mathrm{MHz}, \mathrm{CDCl}_{3}\right) \delta_{\mathrm{C}}: 20.9\left(\mathrm{CH}_{3}\right) ; 109.2(\mathrm{CH}) ; 110.1(\mathrm{CH}) ; 120.1(\mathrm{CH})$; $122.2(\mathrm{CH}) ; 126.1(\mathrm{C}) ; 129.6(\mathrm{CH}) ; 133.9(\mathrm{C}) ; 135.2(\mathrm{C}) ; 159.0$ (C). ${ }^{1} \mathrm{H}-{ }^{13} \mathrm{C}$ HSQC NMR $\left(\mathrm{CDCl}_{3}\right) \delta_{\mathrm{H}} / \delta_{\mathrm{C}}: 2.33 / 20.9 ; 6.29 / 110.1$; 6.68/109.2; 6.98/122.2; 7.15/120.1;7.17/129.6;7.47/120.1; 7.47/ 129.6. ${ }^{1} \mathrm{H}-{ }^{13} \mathrm{C}$ HMBC NMR $\left(\mathrm{CDCl}_{3}\right) \delta_{\mathrm{H}} / \delta_{\mathrm{C}}: 2.33 / 129.6 ; 2.33 /$ $133.9 ; 6.68 / 122.2 ; 6.98 / 110.1 ; 6.98 / 126.1 ; 7.16 / 20.9 ; 7.16 / 120.1$; $7.16 / 129.6 ; 7.16 / 135.2 ; 7.47 / 120.1 ; 7.47 / 133.9$. GC-MS $(\mathrm{m} / z): 201$ (3); 200 (25, M+); 107 (100); 106 (33); 94 (19); 66 (13). HRMS (ESI) calcd. for $\mathrm{C}_{12} \mathrm{H}_{13} \mathrm{~N}_{2} \mathrm{O}^{+}\left[\mathrm{M}+\mathrm{H}^{+}\right]$201.1022, found 201.1032.

$\mathrm{N}$-(4-Methoxyphenyl)-1H-pyrrole-2-carboxamide (7e). The amide was purified by radial thin-layer chromatography on silica gel eluting with a petroleum ether/diethyl ether gradient $(75: 25 \rightarrow 0: 100)$ as white crystals, mp $177.5-178.3{ }^{\circ} \mathrm{C} .{ }^{1} \mathrm{H}$ NMR $(400 \mathrm{MHz}$, acetone$\left.d_{6}\right) \delta_{\mathrm{H}}: 3.77(3 \mathrm{H}, \mathrm{s}) ; 6.18-6.20(1 \mathrm{H}, \mathrm{m}) ; 6.86-6.90(2 \mathrm{H}, \mathrm{m}) ; 6.93-$ $6.95(1 \mathrm{H}, \mathrm{m}) ; 7.01-7.03(1 \mathrm{H}, \mathrm{m}) ; 7.65-7.67(2 \mathrm{H}, \mathrm{m}) ; 9.04(1 \mathrm{H}, \mathrm{s}$ br); $10.78(1 \mathrm{H}, \mathrm{s} \mathrm{br}) .{ }^{13} \mathrm{C}$ NMR $\left(101 \mathrm{MHz}\right.$, acetone- $\left.d_{6}\right) \delta_{\mathrm{C}}: 54.7$ $\left(\mathrm{OCH}_{3}\right) ; 109.1(\mathrm{CH}) ; 109.8(\mathrm{CH}) ; 113.7(\mathrm{CH}) ; 121.3(\mathrm{CH}) ; 121.9$ $(\mathrm{CH}) ; 126.7(\mathrm{C}) ; 132.6(\mathrm{C}) ; 155.8(\mathrm{C}) ; 158.9(\mathrm{C})$. GC-MS $(\mathrm{m} / \mathrm{z})$ : 217 (2), $216\left(\mathrm{M}^{+}, 16\right), 124(8), 123$ (100), 108 (59), 94 (27), 80 (11), 66 (19), 65 (8). HRMS (ESI) $\left[\mathrm{M}+\mathrm{H}^{+}\right]$calcd for $\mathrm{C}_{12} \mathrm{H}_{13} \mathrm{~N}_{2} \mathrm{O}_{2}{ }^{+}$ 217.0972, found 217.0957 .

$\mathrm{N}$-(4-Methoxyphenyl)- $\mathbf{H}$-indole-2-carboxamide (8c). ${ }^{53}$ The amide was purified by radial thin-layer chromatography on silica gel eluting with a petroleum ether/diethyl ether gradient $(80: 20 \rightarrow 0: 100)$ and was isolated as yellow crystals. ${ }^{1} \mathrm{H}$ NMR $\left(400 \mathrm{MHz}\right.$, acetone- $\left.d_{6}\right)$ $\delta_{\mathrm{H}}: 3.80(3 \mathrm{H}, \mathrm{s}) ; 6.91-6.95(2 \mathrm{H}, \mathrm{m}) ; 7.07-7.11(1 \mathrm{H}, \mathrm{m}) ; 7.25(1 \mathrm{H}$, ddd, $J=8.2,7.1,1.1) ; 7.30(1 \mathrm{H}, \mathrm{m}) ; 7.58(1 \mathrm{H}, \mathrm{dd}, J=8.3,0.7) ; 7.64-$ $7.66(1 \mathrm{H}, \mathrm{m}) ; 7.74-7.77(2 \mathrm{H}, \mathrm{m}) ; 9.49(1 \mathrm{H}, \mathrm{s} \mathrm{br}) ; 10.88(1 \mathrm{H}, \mathrm{s} \mathrm{br})$. ${ }^{13} \mathrm{C}$ NMR $\left(100 \mathrm{MHz}\right.$, acetone- $\left.d_{6}\right) \delta_{\mathrm{C}}: 55.7\left(\mathrm{OCH}_{3}\right) ; 103.7(\mathrm{CH})$; $113.2(\mathrm{CH}) ; 114.7(\mathrm{CH}) ; 121.1(\mathrm{CH}) ; 122.5(\mathrm{CH}) ; 122.7(\mathrm{CH})$; 124.8 (CH); 128.8 (C); 132.8 (C); 133.2 (C); 138.0 (C); 157.1 (C); $160.3(\mathrm{C}) .{ }^{1} \mathrm{H}-{ }^{1} \mathrm{H}$ COSY NMR (acetone- $\left.d_{6}\right) \delta_{\mathrm{H}} / \delta_{\mathrm{H}}: 6.93 / 7.75 ; 7.09 /$ 7.25; 7.09/7.65; 7.25/7.58. ${ }^{1} \mathrm{H}-{ }^{13} \mathrm{C}$ HSQC NMR (acetone- $\left.d_{6}\right) \delta_{\mathrm{H}} / \delta_{\mathrm{C}}$ : $3.80 / 55.7 ; 6.93 / 114.7 ; 7.09 / 121.1 ; 7.25 / 124.8 ; 7.30 / 103.7 ; 7.58 /$ $113.2 ; 7.65 / 122.7 ; 7.75 / 122.5 .{ }^{1} \mathrm{H}-{ }^{13} \mathrm{C}$ HMBC NMR (acetone- $d_{6}$ ) $\delta_{\mathrm{H}} / \delta_{\mathrm{C}}: 3.80 / 157.1 ; 6.93 / 114.7 ; 6.93 / 132.8 ; 6.93 / 157.1 ; 7.09 / 113.2 ;$ $7.09 / 128.8 ; 7.25 / 122.7 ; 7.30 / 132.8 ; 7.30 / 138.0 ; 7.58 / 121.0 ; 7.58 /$ $128.8 ; 7.65 / 124.8 ; 7.65 / 138.0 ; 7.75 / 122.5 ; 7.75 / 133.2 ; 7.75 / 157.1$. GC-MS (m/z): $267(8) ; 266\left(\mathrm{M}^{+}, 43\right) ; 144(19) ; 124(8) ; 123$ (100); 116 (11); 115 (4); 108 (25); 89 (24); 80 (2). 
$\mathrm{N}$-Phenylbenzamide (9). The product was obtained following reported methods. ${ }^{54}{ }^{1} \mathrm{H}$ NMR $\left(400 \mathrm{MHz}, \mathrm{CDCl}_{3}\right) \delta_{\mathrm{H}}: 7.15(1 \mathrm{H}, \mathrm{t}, J=$ 7.4); $7.36(2 \mathrm{H}, \mathrm{t}, J=7.9) ; 7.44-7.48(2 \mathrm{H}, \mathrm{m}) ; 7.52-7.56(1 \mathrm{H}, \mathrm{m})$; $7.64(2 \mathrm{H}, \mathrm{d}, J=7.8)$; $7.85-7.87(2 \mathrm{H}, \mathrm{m}) ; 7.93(1 \mathrm{H}, \mathrm{s} \mathrm{br}) .{ }^{13} \mathrm{C}$ NMR $\left(101 \mathrm{MHz}, \mathrm{CDCl}_{3}\right) \delta_{\mathrm{C}}: 120.2(\mathrm{CH}) ; 124.5(\mathrm{CH}) ; 127.0(\mathrm{CH}) ; 128.7$ $(\mathrm{CH}) ; 129.1(\mathrm{CH}) ; 131.8(\mathrm{CH}) ; 135.0(\mathrm{C}) ; 137.9(\mathrm{C}) ; 165.8(\mathrm{C})$.

$\mathrm{N}$-Phenyl-1 $\mathrm{H}$-indole-3-carboxamide (16a). The amide was not isolated but detected by GC-MS. GC-MS $(\mathrm{m} / z): 237(17) ; 236$ $(\mathrm{M}+, 100) ; 235$ (85); 220 (12); 219 (45); 218 (11); 217 (22); 208 (14); 207 (28); 206 (14); 180 (11); 118 (15); 109 (12); 90 (12), 89 (15).

Chromeno[3,4-b]indol-6(7H)-one (18). The chromeno was purified by column chromatography on silica gel eluting with petroleum ether/diethyl ether gradient $(80: 20 \rightarrow 60: 40)$ and recrystallized from $\mathrm{CH}_{2} \mathrm{Cl}_{2}$ as white crystals, mp 290.0-291.0 ${ }^{\circ} \mathrm{C} .{ }^{1} \mathrm{H}$ NMR $\left(400 \mathrm{MHz}, \mathrm{DMSO}-d_{6}\right) \delta_{\mathrm{H}}: 7.33(1 \mathrm{H}, \mathrm{t}, J=7.20) ; 7.42-7.53(4 \mathrm{H}, \mathrm{m})$; $7.62(1 \mathrm{H}, \mathrm{d}, J=8.40) ; 8.40-8.45(2 \mathrm{H}, \mathrm{m}) ; 12.69(1 \mathrm{H}, \mathrm{s} \mathrm{br}) .{ }^{13} \mathrm{C}$ NMR $\left(101 \mathrm{MHz}\right.$, DMSO- $\left.d_{6}\right) \delta_{\mathrm{C}}: 113.4(\mathrm{CH}) ; 116.9(\mathrm{C}) ; 118.4(\mathrm{C})$; $119.9(\mathrm{CH}) ; 121.3(\mathrm{C}) ; 121.4(\mathrm{C}) ; 121.6(\mathrm{CH}) ; 122.6(\mathrm{CH}) ; 123.6$ $(\mathrm{CH}) ; 124.9(\mathrm{CH}) ; 127.2(\mathrm{CH}) ; 127.4(\mathrm{CH}) ; 139.8(\mathrm{C}) ; 150.4(\mathrm{C})$; $155.3(\mathrm{C}) .{ }^{1} \mathrm{H}-{ }^{1} \mathrm{H}$ COSY NMR (DMSO- $\left.d_{6}\right) \delta_{\mathrm{H}} / \delta_{\mathrm{H}}: 7.33 / 7.48 ; 7.33 /$ 8.43; 7.48/7.62; 7.48/8.43. ${ }^{1} \mathrm{H}-{ }^{13} \mathrm{C}$ HSQC NMR (DMSO- $d_{6}$ ) $\delta_{\mathrm{H}} / \delta_{\mathrm{C}}$ : 7.33/121.6; 7.48/116.9; 7.48/124.9; 7.48/127.2; 7.48/127.4; 7.62/ 113.4; 8.43/122.6; 8.43/123.6. ${ }^{1} \mathrm{H}-{ }^{13} \mathrm{C}$ HMBC NMR (DMSO- $d_{6}$ ) $\delta_{\mathrm{H}} / \delta_{\mathrm{C}}: 7.33 / 113.4 ; 7.33 / 121.4 ; 7.48 / 122.6 ; 7.48 / 124.9 ; 7.62 / 121.4 ;$ $8.43 / 119.9 ; 8.43 / 121.3 ; 8.43 / 127.2 ; 8.43 / 127.4 ; 8.43 / 150.4$. GC-MS $(\mathrm{m} / z): 236(16) ; 235\left(\mathrm{M}^{+}, 100\right) ; 206(6) ; 179(7) ; 178(10) ; 177(5)$; 153 (7); 152 (23); 151 (11); 150 (5); 76 (15); 75 (6). HRMS (ESI) $\left[\mathrm{M}+\mathrm{H}^{+}\right]$calcd for $\mathrm{C}_{15} \mathrm{H}_{10} \mathrm{NO}_{2}{ }^{+} 236.0706$, found 236.0716.

\section{ASSOCIATED CONTENT}

\section{S Supporting Information}

Copies of ${ }^{1} \mathrm{H},{ }^{13} \mathrm{C}$, COSY, HSQC, and HMBC NMR spectra of all compounds and spectroscopic characterization and full assignation of products $4 d, 4 e, 4 h, 4 i, 5 b, 5 c, 5 d, 5 e, 5 f$, and $6 b$ are available in Experimental Supporting Information (SI-1). Schematic profiles (Figures S1 and S2), xyz coordinates, and total energies in atomic units of the species calculated are available in Calculation Supporting Information (SI-2). This material is available free of charge via the Internet at http:// pubs.acs.org.

\section{AUTHOR INFORMATION}

\section{Corresponding Author}

*Fax: (+54) 351-4333030/4334174. Phone: (+54) 351-4334170/73.

E-mail: rossi@fcq.unc.edu.ar.

\section{ACKNOWLEDGMENTS}

This work was supported in part by Agencia Córdoba Ciencia, the Consejo Nacional de Investigaciones Cientificas y Técnicas (CONICET), Secretaría de Ciencia y Técnología, Universidad Nacional de Córdoba, and Fondo para la Investigación Científica y Tecnológica Argentina. V.A.V., J.F.G., M.E.B., and J.I.B. gratefully acknowledge receipt of fellowships from CONICET.

\section{REFERENCES}

(1) Chancellor, D. R.; Davies, K. E.; De Moor, O.; Dorgan, C. R.; Johnson, P. D.; Lawrence, D.; Lecci, C.; Maillol, C.; Middleton, P. J.; Nugent, G.; Poignant, S. D.; Potter, A. C.; Price, P. D.; Pye, R, J.; Storer, R.; Tinsley, J. M.; van Well, R.; Vickers, R.; Vile, J.; Wilkes, F. J.; Wren, S. P.; Wynne, G. M. J. Med. Chem. 2011, 54, 3241-3250.

(2) Michel, K. H.; Boeck, L. D.; Hoehn, M. M.; Jones, N. D.; Chaney, M. O. J. Antibiot. 1984, 37, 441-445.

(3) (a) Klimešová, V.; Kočí, J.; Waisser, K.; Kaustová, J.; Möllmann, U. Eur. J. Med. Chem. 2009, 44, 2286-2293. (b) Rodríguez, A. D.; Ramírez, C.; Rodríguez, I. I.; González, E. Org. Lett. 1999, 1, 527-530.
(4) Tipparaju, S. K.; Joyasawal, S.; Pieroni, M.; Kaiser, M.; Brun, R.; Kozokowski, A. P. J. Med. Chem. 2008, 51, 7344-7347.

(5) (a) Aiello, S.; Wells, G.; Stone, E. L.; Kadri, M.; Bazzi, R.; Bell, D. R.; Stevens, M. F. G.; Matthews, C. S.; Bradshow, T. D.; Westwell, A. D. J. Med. Chem. 2008, 51, 5135-5139. (b) Mckee, M. L.; Kerwin, S. M. Bioorg. Med. Chem. 2008, 16, 1775-1783.

(6) Dunwell, D. W.; Evans, D. J. Med. Chem. 1977, 20, 797-801.

(7) Rostom, S. A. F.; Fahmy, H. T. Y.; Saudi, M. N. S. Sci. Pharm. 2003, 71, 57-74.

(8) Roman-Blas, J. A.; Castaneda, S.; Cutolo, M.; Herrero-Beaumont, G. Arthritis Care Res. 2010, 62, 1588-1593.

(9) Yamada, M.; Sato, Y.; Kobayashi, K.; Konno, F.; Soneda, T.; Watanabe, T. Chem. Pharm. Bull. 1998, 46, 445-451.

(10) Kumar, D.; Jacob, M. R.; Reynolds, M. B.; Kerwin, S. M. Bioorg. Med. Chem. 2002, 10, 3997-4004.

(11) Ko, C.-W.; Tao, Y.-T.; Danel, A.; Krzeminska, L.; Tomasik, P. Chem. Mater. 2001, 13, 2441-2446.

(12) Tian, Y.; Chen, C.-Y.; Yang, C.-C.; Young, A. C.; Yang, S.-H.; Chen, W.-C.; Jen, A. K.-Y. Chem. Mater. 2008, 20, 1977-1987.

(13) Kocher, C.; Smith, P.; Weder, C. J. Mater. Chem. 2002, 12, 2620-2626.

(14) (a) Hein, D. W.; Alheim, R. J.; Leavitt, J. J. J. Am. Chem. Soc. 1957, 79, 427-429. (b) So, Y.-H.; Heeschen, J. P. J. Org. Chem. 1997, 62, 3552-3561. (c) Ertan, T.; Yildiz, I.; Tekiner-Gulbas, B.; Bolelli, K.; Temiz-Arpaci, O.; Ozkom, S.; Kaynok, F.; Yalcin, I.; Aki, E. Eur. J. Med. Chem. 2009, 44, 501-510.

(15) Harikrishnan, L. S.; Kamau, M. G.; Herpin, T. F.; Morton, G. C.; Liu, Y.; Cooper, C. B.; Salvati, M. E.; Qiao, J. X.; Wang, T. C.; Adam, L. P.; Taylor, D. S.; Chen, A. Y. A.; Yin, X.; Seethala, R.; Peterson, T. L.; Nirschl, D. S.; Miller, A. V.; Weigelt, C. A.; Appiah, K. K.; O’Connell, J. C.; Lawrence, R. M. Bioorg. Med. Chem. Lett. 2008, $18,2640-2644$.

(16) (a) Chang, J.; Zhao, K.; Pan, S. Tetrahedron Lett. 2002, 43, 951954. (b) Praveen, C.; Kumar, K. H.; Muralidharan, D.; Perumal, P. T. Tetrahedron 2008, 64, 2369-2374. (c) Vinsova, J.; Cermakova, K.; Tomeckova, A.; Ceckova, M.; Jampilek, J.; Cermak, P.; Kunes, J.; Dolezale, M.; Staud, F. Bioorg. Med. Chem. 2006, 14, 5850-5865. (d) Liao, C.-H.; Wang, C.-S.; Sheu, H.-S.; Lai, C. K. Tetrahedron 2008, 64, 7977-7985. (e) Riadi, Y.; Mamouni, R.; Azzalou, R.; El Haddad, M.; Routier, S.; Guillaumet, G.; Lazar, G. Tetrahedron Lett. 2011, 52, 3492-3495.

(17) Kumar, A.; Sharma, S.; Maurya, R. A. Tetrahedron Lett. 2010, 51, 6224-6226.

(18) (a) El-Sheik, M. I.; Marks, A.; Biehl, E. R. J. Org. Chem. 1981, 46, 3256-3259. (b) Hrutfiord, B. F.; Bunnett, J. F. J. Am. Chem. Soc. 1958, 80, 2021-2022. (c) Hrutfiord, B. F.; Bunnett, J. F. J. Am. Chem. Soc. 1961, 83, 1691-1697.

(19) (a) Evindar, G.; Batey, R. A. J. Org. Chem. 2006, 71, 1802-1808. (b) Altenhoff, G.; Glorius, F. Adv. Synth. Catal. 2004, 346, 1661-1166. (c) Barbero, N.; Carril, M.; San Martin, R.; Domínguez, E. Tetrahedron 2007, 63, 10425-10432. (d) Vaillard, V. A.; Rossi, R. A.; Martín, S. E. Org. Biomol. Chem. 2011, 9, 4927-4935.

(20) Bonnamour, J.; Bolm, C. Org. Lett. 2008, 10, 2665-2667.

(21) (a) Park, Y.-T.; Jung, C.-H.; Kim, K.-W.; Kim, H. S. J. Org. Chem. 1999, 64, 8546-8556. (b) Mayouf, A. M.; Park, Y.-T. J. Photochem. Photobiol., A 2002, 150, 115-123. (c) Mayouf, A. M. J. Photochem. Photobiol., A 2005, 172, 258-268.

(22) (a) Ueda, S.; Nagasawa, H. J. Org. Chem. 2009, 74, 4272-4277. (b) Ueda, S.; Nagasawa, H. Angew. Chem., Int. Ed. 2008, 47, 64116413.

(23) (a) Guru, M. M.; Ali, M. A.; Punniyamurthy, T. Org. Lett. 2011, 13, 1194-1196. (b) Guru, M. M.; Ali, M. A.; Punniyamurthy, T. J. Org. Chem. 2011, 76, 5295-5308.

(24) Viirre, R. D.; Evindar, G.; Batey, R. A. J. Org. Chem. 2008, 73, $3452-3459$.

(25) For reviews, see: (a) Rossi, R. A.; Pierini, A. B.; Santiago, A. N.; In Organic Reactions; Paquette, L. A., Bittman, R., Eds.; Wiley \& Sons: Hoboken, NJ, 1999; pp 1-271. (b) Rossi, R. A.; Pierini, A. B.; Peñéñory, A. B. Chem. Rev. 2003, 103, 71-167. (c) Rossi, R. A. In 
Synthetic Organic Photochemistry; Griesberck, A. G., Mattay, J., Eds.; Marcel Dekker: New York, 2005; Vol. 12, Chapter 15, pp 495-527.

(26) Goehring, R. R.; Sachdeva, Y. P.; Pisipati, J. S.; Wolfe, M. C.

J. Am. Chem. Soc. 1985, 107, 435-443.

(27) Bowman, W. R.; Heaney, H.; Smith, P. H. G. Tetrahedron Lett. 1982, 23, 5093-5096.

(28) Barolo, S. M.; Teng, X.; Cuny, G. D.; Rossi, R. A. J. Org. Chem. 2006, 71, 8493-8499.

(29) Budén, M. E.; Dorn, V. B.; Gamba, M.; Pierini, A. B.; Rossi, R. A. J. Org. Chem. 2010, 75, 2206-2218.

(30) Budén, M. E.; Vaillard, V. A.; Martín, S. E.; Rossi, R. A. J. Org. Chem. 2009, 74, 4490-4498.

(31) Laha, J. K.; Barolo, S. M.; Rossi, R. A.; Cuny, G. D. J. Org. Chem. 2011, 76, 6421-6425.

(32) Vaillard, V. A.; Budén, M. E.; Martín, S. E.; Rossi, R. A. Tetrahedron Lett. 2009, 3529-3532.

(33) (a) Chahma, M.; Combellas, C.; Thiébault, A. J. Org. Chem. 1995, 60, 8015-8022. (b) Chahma, M.; Combellas, C.; Thiébault, A. Synthesis 1994, 366-368. (c) Chahma, M.; Combellas, C.; Marzouk, H.; Thiébault, A. Tetrahedron Lett. 1991, 32, 6121-6124.

(34) (a) Mahboobi, S.; Teller, S.; Pongratz, H.; Hufsky, H.; Sellmer, A.; Botzki, A.; Uecker, A.; Beckers, T.; Baasner, S.; Schächtele, C.; Überall, F.; Kassack, M. U.; Dove, S.; Böhmer, F.-D. J. Med. Chem. 2002, 45, 1002-1018. (b) Beccalli, E. M.; Bernasconi, A.; Borsini, E.; Broggini, G.; Rigamonti, M.; Zecchi, G. J. Org. Chem. 2010, 75, 69236932.

(35) These reactions were performed and reported previously (see ref 32). The product was assigned as $C$-coupling substitution; later, experiments by RMN spectroscopy (COSY, HSQC, HMBC, and NOESY) were performed, which allowed us to determine that the product obtained is the $\mathrm{O}$-coupling substitution.

(36) The potentiometric determination of halide ions was used as a tool for balance mass determination. In an ideal case, if the conversion is complete, the dehalogenation is nearly $100 \%$.

(37) The $\mathrm{p} K_{\mathrm{a}}$ of pyrrole is 23.0 and the $\mathrm{p} K_{\mathrm{a}}$ of $N$-phenyl benzamide is 18.8 in DMSO; see: Bordwell, F. G. Acc. Chem. Res. 1988, 21, 456-463. However pyrrole is a poor approximation to $\mathrm{N}$-phenyl- $1 \mathrm{H}$ pyrrole-2-carboxamide.

(38) B3LYP/6-31+g* was used with PCM $(\mathrm{MeOH})$.

(39) When DMSO was used as a solvent, the same difference energy $\left(2.1 \mathrm{kcal} \mathrm{mol}^{-1}\right)$ was obtained. See the Calculation Supporting Information (SI-2).

(40) We propose that the electron could come from different sources: (a) from the excited anion of the substrate to the substrate anion (homocoupled redox reaction) or (b) from the base, which acts as entrainment reagent.

(41) (a) Baumgartner, M. T.; Pierini, A. B.; Rossi, R. A. J. Org. Chem. 1993, 58, 2593-2598. (b) Tempesti, T. C.; Pierini, A. B.; Baumgartner, M. T. J. Org. Chem. 2005, 70, 6508-6511.

(42) The structures of all conformer are indicated in Figures S1 and S2 in the Supporting Information Calculations file.

(43) (a) Uranga, J. G.; Vera, D. M. A.; Santiago, A. N.; Pierini, A. B. J. Org. Chem. 2006, 71, 6596-6599. (b) Pierini, A. B.; Santiago, A. N.; Allende, S. G.; Vera, D. M. A. ARKIVOC 2003, Part $x, 477-490$. (c) Pierini, A. B.; Vera, D. M. A. J. Org. Chem. 2003, 68, 9191-9199. (44) Frisch, M. J.; Trucks, G. W.; Schlegel, H. B.; Scuseria, G. E.; Robb, M. A.; Cheeseman, J. R.; Scalmani, G.; Barone, V.; Mennucci, B.; Petersson, G. A.; Nakatsuji, H.; Caricato, M.; Li, X.; Hratchian, H. P.; Izmaylov, A. F.; Bloino, J.; Zheng, G.; Sonnenberg, J. L.; Hada, M.; Ehara, M.; Toyota, K.; Fukuda, R.; Hasegawa, J.; Ishida, M.; Nakajima, T.; Honda, Y.; Kitao, O.; Nakai, H.; Vreven, T.; Montgomery, Jr., J. A.; Peralta, J. E.; Ogliaro, F.; Bearpark, M.; Heyd, J. J.; Brothers, E.; Kudin, K. N.; Staroverov, V. N.; Kobayashi, R.; Normand, J.; Raghavachari, K.; Rendell, A.; Burant, J. C.; Iyengar, S. S.; Tomasi, J.; Cossi, M.; Rega, N.; Millam, N. J.; Klene, M.; Knox, J. E.; Cross, J. B.; Bakken, V.; Adamo, C.; Jaramillo, J.; Gomperts, R.; Stratmann, R. E.; Yazyev, O.; Austin, A. J.; Cammi, R.; Pomelli, C.; Ochterski, J. W.; Martin, R. L.; Morokuma, K.; Zakrzewski, V. G.; Voth, G. A.; Salvador, P.; Dannenberg, J. J.; Dapprich, S.; Daniels, A. D.; Farkas, Ö.; Foresman, J. B.; Ortiz, J. V.;
Cioslowski, J.; Fox, D. J. Gaussian 09, Revision A.1; Gaussian, Inc.: Wallingford, CT, 2009.

(45) (a) Lee, C.; Yang, W.; Parr, R. G. Phys. Rev. B: Condens. Matter Mater. Phys. 1988, 37, 785-789. (b) Becke, A. D. Phys. Rev. A: At., Mol., Opt. Phys. 1988, 38, 3098-3100. (c) Miehlich, B.; Savin, A.; Stoll, H.; Preuss, H. Chem. Phys. Lett. 1989, 157, 200-206.

(46) (a) Miertus, S.; Scrocco, E.; Tomasi, J. Chem. Phys. 1981, 55, 117-129. (b) Miertus, S.; Tomasi, J. Chem. Phys. 1982, 65, 239-245. (c) Cossi, M.; Barone, V.; Cammi, R.; Tomasi, J. Chem. Phys. Lett. 1996, 255, 327-335.

(47) Guide to Uplamping for High Intensity Discharge Lamps; Philips Electronics UK Ltd: Surrey, U. K., 2010;http://www. ribaproductselector.com/Docs/9/05799/external/COL605799.pdf

(48) Beugelmans, R.; Chbani, M. Bull. Soc. Chim. Fr. 1995, 132, 290305 .

(49) Carlock, J. T.; Bradshaw, J. S.; Stanovnik, B.; Tiler, M. J. Org. Chem. 1977, 42, 1883-1885.

(50) George, B.; Papadopoulos, E. P. J. Org. Chem. 1977, 42, 441443.

(51) Chen, W.; Wang, M.; Li, P.; Wang, L. Tetrahedron 2011, 67, 5913-5919. The ${ }^{13} \mathrm{C}$ NMR spectrum is in agreement with the literature.

(52) Harris, R. L. N. Aust. J. Chem. 1974, 27, 2635-2643.

(53) Lee, A. R.; Huang, W. H.; Cherng, J. Y. Chin. Pharm. J. 1994, 46, 307-311.

(54) Furniss, B. S.; Hannaford, A. J.; Smith, P. W. G.; Tatchell, A. R. Vogel's Textbook of Practical Organic Chemistry, 5th ed.; AddisonWesley Longman Ltd: Essex, U. K., 1989; p 1274. 